
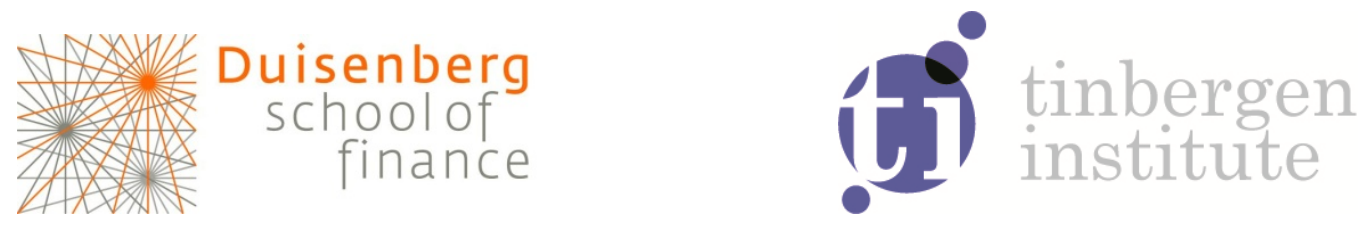

Duisenberg school of finance - Tinbergen Institute Discussion Paper

TI 13-013/ VI/ DSF 50

\title{
Financial Frictions and the Credit Transmission Channel: \\ Capital Requirements and Bank Capital
}

Lucyna Gornicka

Sweder van Wijnbergen 
Tinbergen Institute is the graduate school and research institute in economics of Erasmus University Rotterdam, the University of Amsterdam and VU University Amsterdam.

More TI discussion papers can be downloaded at http://www.tinbergen.nl

Tinbergen Institute has two locations:

Tinbergen Institute Amsterdam

Gustav Mahlerplein 117

1082 MS Amsterdam

The Netherlands

Tel.: +31(0)205251600

Tinbergen Institute Rotterdam

Burg. Oudlaan 50

3062 PA Rotterdam

The Netherlands

Tel.: +31(0)10 4088900

Fax: +31(0)104089031

Duisenberg school of finance is a collaboration of the Dutch financial sector and universities, with the ambition to support innovative research and offer top quality academic education in core areas of finance.

DSF research papers can be downloaded at: http://www.dsf.nl/

Duisenberg school of finance

Gustav Mahlerplein 117

1082 MS Amsterdam

The Netherlands

Tel.: +31(0)20 5258579 


\title{
Financial Frictions and the Credit Transmission Channel: Capital Requirements and Bank Capital
}

\author{
Lucyna Gornicka and Sweder van Wijnbergen
}

Tinbergen Institute and Department of Economics, University of Amsterdam

\begin{abstract}
We investigate actual capital chosen by banks in presence of capital minimum requirements and expost penalties for violating them. The model yields excess capital that is always positive and increases during times of distress in the economy, which is in line with empirical evidence. Next, we show that in presence of ex-post violation penalties the introduction of the conservation buffer under Basel III will not contribute to lowering the pro-cyclicality of capital regulations. The countercyclical buffer proposed under Basel III is then even more desirable as it significantly attenuates fluctuations of actual capital also when the penalties are accounted for.
\end{abstract}

Keywords: capital requirements, Basel regulatory framework, excess capital, countercyclical buffer, market discipline.

JEL Classification: G21, G28, E32, E44

\section{Introduction and Literature Overview}

The recent global financial crisis, which is already being compared in magnitude and possible long-term consequences to the Great Depression, has exposed the weaknesses of financial markets as well as their regulatory framework. In particular, it has become clear that minimum capital requirements in their current form are not sufficient to keep banks from increased risk-taking and, as safety buffers, to protect banks from default. The loss absorption capacity of the banking system is by now widely considered to be too low. In addition, capital regulations may have even contributed to the severity of the recent crisis: it is widely accepted that capital requirements are pro-cyclical (Bec and Gollier (2009)), and thus amplify business cycle fluctuations (Blum and Hellwig (1995), Kashyap and Stein (2004) and Heid (2007)). In the light of above considerations a major overhaul of the system of capital requirements and more generally of the structure 
of bank regulation has been agreed upon and is to be implemented over the coming years (Basel Committee (2010)). Under Basel-III capital requirements will be tightened in various ways and a first step has been made to create a less pro-cyclical regulatory framework. At the same time the plans to implement this new system have triggered a wide set of questions: will tightening requirements turn out to be an impediment for economic growth in the long term? Will it delay recovery in the short term? Will it reduce or even eliminate pro-cyclicality of the system? What will in fact be the impact on actual capital ratios? Will banks respond by increasing their capital or will they just absorb the new rules by lowering already existing buffers they hold in excess of current regulatory ratios?

While answers to most of these questions will require a general equilibrium framework, any general equilibrium effects will be triggered by changes in the banks' actual capital levels. In this paper we focus entirely on this issue, i.e. we investigate the direct impact of minimum requirements on banks' capital choices, before general equilibrium effects come into play. We believe that a precise analysis of the actual capital's dynamics in presence of capital regulations is a necessary first step towards further welfare analysis and policy implications. For example, if in equilibrium banks' actual capital responds more than one-to-one to a raise in minimum requirements, the pro-cyclical character of capital regulations will be additionally magnified, which in turn should be taken into account when deciding on changes in regulatory capital ratios. Without a thorough investigation of the relation between regulatory and actual capital no good answers to questions about impact of capital requirements on output growth, cyclicality or the severity of financial crises can be given.

The literature does not devote much space to a detailed analysis of the effects of regulatory capital on banks' actual capital choices: so far it is standard to assume that capital minima have an effect on banks' capital decisions only if they bind, i.e. when economic capital preferred by banks in absence of regulations is below the regulatory minimum. In such case it is usually assumed that banks set their common equity at the level exactly equal to the latter (Elizalde and Repullo $(2007)^{1}$ ).

On the contrary, one of the stylized facts is that banks hold own capital in excess of the regulatory minimum. This in turn is explained by banks' attempts to avoid costly consequences of not meeting capital requirements, such as increased funding costs, lowered ratings, regulatory penalties and compulsory recapitalizations (Lindquist (2004) confirms this hypothesis for Norwegian banks). Still, despite empirical evidence, most of the economic literature assumes zero excess capital buffers. Positive buffers, if introduced, are obtained via capital adjustment costs (Estrella (2004)), fixed ex-post fines for not meeting capital requirements (Milne (2002)) or random audits by regulators (Milne and Whalley (2001)). However, while yielding positive excess capital levels, these solutions are mechanical and lack realism in resembling true regulatory procedures used in case of a requirements' violation. A notable exception from this critique is a recent paper by Repullo and Suarez (2012), who obtain positive buffers in a multiperiod setting, where banks cannot recapitalize on an ongoing basis. Positive excess capital emerges as a result of banks' precautionary strategy. Nonetheless, the buffers in Repullo and Suarez (2012) move procyclically (i.e. are higher during expansion times), which is against the empirical evidence available at this point (e.g Lindquist (2004)).

\footnotetext{
${ }^{1}$ Elizalde and Repullo (2007) do obtain positive excess capital for some parameter values, but this is achieved by imposing a severe closing rule on banks. Once the closing rule is relaxed, actual capital is always equal to the maximum of economic capital and regulatory capital).
} 
This study attempts to fill the abovementioned gap in the analysis of capital regulations. We do it by introducing regulatory and "market" penalties for not meeting capital requirements. We show that in presence of such penalties banks have direct incentives to keep capital always above the regulatory minimum. Imposed regulatory penalties are assumed to be temporary and proportional to the size of violation, which aims at representing properties of the regulatory penalties used in practice.

For this purpose we construct a partial equilibrium model of the banking sector. Although this restrains us from a proper evaluation of the welfare implications of capital regulations, we believe that this setting is well-suited for analyzing and fully understanding the first-order effects of minimum requirements and ex-post penalties, i.e. via their impact on actual capital. It should be seen as a starting point on the way to developing a general equilibrium model, in which questions about the macroeconomic impact of capital regulations can be answered.

The results of our analysis show that incorporating regulatory penalties to the financial sector model yields actual capital choices that can be supported by empirical evidence. We also investigate the capital requirements currently in force. In our model the countercyclical buffer envisioned under Basel-III provisions will significantly reduce (although not eliminate) the pro-cyclicality of capital requirements. Another key result is that in presence of ex-post violation penalties the market disciplining role of Tier 2 capital is severely restricted. In fact, increasing the required level of the Tier-2-type of capital (as recently proposed by the European Commission ${ }^{2}$ ) almost entirely eliminates its market disciplining role in our framework.

This paper is organized as follows. Section 2 describes the proposed bank's optimization problem; Section 3 introduces the concepts of economic, actual, and regulatory capital. Section 4 contains numerical results of the main analysis and of the abovementioned additional investigation of the Basel-II and Basel-III capital requirements and the role of Tier 2 capital. Section 5 gives main conclusions, further analysis steps and possible extensions.

\subsection{Literature backgroud}

"The fundamental question which international debates on bank capital adequacy have therefore never answered and indeed hardly addressed is what overall level of bank capital is optimal"

\section{A. Turner (A Regulatory Response to the Global Banking Crisis (2009))}

The outburst of the recent financial crisis has provoked a discussion on macroprudential policies that would prevent the financial system from similar breakdowns in the future. Galati and Moessner (2011) present a comprehensive overview of the definitions, goals and possible tools for macroprudential policies appearing in the literature over recent years. Examples of such measures include capital requirements but also interest rate surcharges to particular types of banks' activities, tightened supervisory regulations regarding the financial institutions' accounting and disclosure standards, capital insurance, limitations to dividend payments and liquidity coverage ratios.

\footnotetext{
${ }^{2}$ See Section 4.4 for details.
} 
While being widely applied in the regulatory practice, current regulatory capital ratios do not follow from any theory of optimal capital choices directly. As Turner (2009) argues, the absolute capital minima negotiated in the 1980s under Basel I - the predecessor of Basel II - were a result of a pragmatic compromise between different objectives of negotiating countries. The Basel-II regulations, despite introducing some changes in the definitions of regulatory capital and conditioning it on the risk level carried by various assets, were in fact intentionally calibrated, so that the average capital requirements do not significantly deviate from the Basel I values. Moreover, empirical evidence shows that actual capital levels held by banks increased significantly after first regulatory guidelines were introduced in early 1980s (Wall and Peterson (2002)), implying that the economic capital had lied below the new capital ratios. This raises questions concerning the drivers of such increases in the actual capital holdings and the interaction mechanism between actual capital and further changes in regulatory minimum requirements.

At the same time concerns over efficiency and macroeconomic consequences of the solutions being put forward have been rising. Cournede and Slovik (2011) estimate that implementation of Basel III will decrease the annual GDP growth by 0.05 to 0.15 percentage point in the medium term. Roger and Vitek (2012) report a 0.5 percentage point decrease of the global output (also in medium term) in response to a 1 percent increase in capital requirements when accounting for international spillover effects. Kashyap and Stein (2004), among many others, point at the pro-cyclical character of current capital requirements leading to exacerbated business cycle fluctuations and as a solution suggest implementation of a family of risk curves instead of a single risk curve to calculate corresponding capital charges. Finally, Gordy (2003) asserts serious flaws in the calculation method of the risk-sensitive capital charges under Basel framework. He showed that, while both Basel-II and Basel-III capital charges are known to be portfolio-invariant, the conditions necessary for the contribution of a given instrument to a portfolio's Value at Risk to be portfolio-invariant are not satisfied in the real world.

Taking another perspective, several empirical studies have confirmed that banks keep actual capital above the regulatory minima. Jokipii and Milne (2008) found that the average capital buffer in years 1997-2004 in a range of European countries varied from 1.46 percentage points (above the regulatory minimum of $8 \%$ of RWA) in UK to 9.18 percentage points in Slovakia. Saurina et al. (2004), Lindquist (2004), and Stolz and Wedow (2005) showed that the capital buffers of Spanish, Norwegian and German banks respectively move countercyclically over the business cycle. Finally, many other studies confirmed that size of capital buffers depends on a high number of factors, such as size and demographic diversity of banks, portfolio risks, ownership structure and access to capital markets (Gorton and Rosen (1995), Estt (1997), Salas and Saurina (2000)).

Turning to theoretical analysis, Milne and Whalley (2001) show that in their continuous-time setting with random regulatory audits of capital levels and fixed ex-post penalties banks hold a buffer of free capital above the regulatory minimum. Estrella (2004) considers a bank's optimal capital choice in a model with capital regulation, where capital and dividend payments adjustment costs are present, but he focuses on the pro-cyclical character of capital regulations. Although both random audits with fixed fines and capital adjustment costs introduce additional motive for keeping excess capital over the regulatory minimum, the two solutions lack realism in resembling the consequences of breaking capital regulations observed in practice. As 
it will be argued in Section 3, regulatory measures used towards banks that do not meet capital requirements are temporary and aimed at restoring the bank's financial soundness rather than worsening the bank's condition by taking more capital from it (for example via fines). From this point of view capital adjustment costs can be seen as an additional channel magnifying the impact of ex-post penalties on banks' behavior. Taking another approach, Elizalde and Repullo (2007) construct a simple banking sector model and compare regulatory capital levels with the actual capital chosen by banks first in absence of regulations and then under capital requirements (binding for the beginning of period capital choice only) in force. They find that there is no direct relationship between the economic and regulatory capital, as the two capital concepts depend on partially different sets of variables. Finally, Gerali et al. (2010) introduce capital requirements into a DSGE model. Capital regulations are modeled as a target capital level which banks aim at achieving. Missing the target is "penalized" via quadratic interest rate adjustment costs, which resembles the approach of Estrella (2004). Benes and Kumhof (2011) develop a similar general equilibrium setting and show that in presence of financial-accelerator-type banking sector and regulatory penalties for insufficient net worth, countercyclical capital requirements adjusting in response to bank's portfolio performance would significantly increase welfare.

The literature on capital requirements also looks at the structure of capital requirements, especially on the role of the so-called Tier-2 capital ${ }^{3}$. Allowing banks to count Tier-2-type capital as part of regulatory capital under Basel II has been justified by the claim that it induces higher market discipline: directly, through higher yields demanded by the subordinate creditors in response to higher risks taken by the bank; and indirectly, by signaling increased risk-taking behavior to the regulatory authorities through the associated higher spreads on interest rates. However, many recent papers (e.g. Barrell, Davis, Fic and Karim (2011)) argue that - as equity is always a better disciplining tool than debt because of its lower seniority in distress situations - increasing Tier-2 capital at the expense of a lower share of common equity in banks' liabilities could well induce higher risk-taking by the banks involved. The little evidence available from empirical investigation of the Tier 2 role seems to supports this critique (Morgan and Stiroh (2005), Krishnan et al. (2005), Francis and Osborne (2009)).

Taken together, the above literature overview indicates two main problems. First, the adequacy of current minimum capital requirements for macroprudential goals is questionable. Secondly, theoretical models of capital regulations so far inadequately deal with actual capital choices made by banks and fail to realistically incorporate regulatory responses to violations of minimum capital ratios. They are hence insufficient for inference of any precise policy implications. All in all, further developments in this research area are needed.

\footnotetext{
${ }^{3}$ Tier 1 consists of common equity, retained earnings and preferred stock, while Core Tier 1 consists of common equity and retained earnings only. Tier 2 includes "hybrid" debt/equity capital instruments, subordinated debt, undisclosed reserves, revaluation and general loan-loss reserves
} 


\section{The Model}

\subsection{Motivation}

In order to investigate banks' capital decisions, we construct a simple partial equilibrium model of the banking sector. This setting choice restrains us from analysis of welfare implications of capital regulations, but we believe it is justified by our focus on the first-order effects of minimum requirements and ex-post penalties, which is through their impact on actual capital held by banks.

Moreover, for simplicity of exposition, we focus on the liabilities-side problem of the bank, assuming that the bank's portfolio risk is exogenous and fixed. Allowing for endogenous portfolio risk choice and consequent risk-shifting issues is a desirable future extension of this study.

On the liabilities side, we allow the bank to choose between deposits, subordinate debt and common equity as funding sources. In order to avoid corner solutions, we introduce a moral hazard friction into our framework, in line with Gertler and Karadi (2011), i.e. we assume that the bank's manager can embezzle a fraction of the bank's assets each period, and that the friction is increasing in the share of subordinate debt in the bank's liabilities. Introducing subordinate debt allows us to investigate the substitution effects of increasing capital requirements as well as look at the impact of capital requirements on the marketdisciplining role of risk-sensitive Tier 2 capital.

In Section 4.3 we consider an extended version of the model, where we allow the portfolio risk parameter to vary along the business cycle because we also want to analyze the cyclical properties of the proposed Basel-III capital requirements regime - in particular of the so called anti-cyclical buffer that is part of the Basel-III proposals. To that end we need to introduce a business cycle to our model, which we do by allowing the portfolio risk parameter to vary between two values, corresponding to expansion and recession times. The transition between states is governed by a transition matrix calibrated on US data.

\subsection{Model structure}

We consider a financial sector with infinitely many equally-sized intermediaries (possessing the same intermediation technology) and focus on the problem of the representative bank. In this simple partial equilibrium model banks serve as intermediaries between investors (where we distinguish between depositors, subordinate debt owners and shareholders), who want to make profits on their capital holdings, and firms, who need capital to finance their investments. Each period a fraction $p_{t}$ of firms defaults, in which case the representative bank is able to recover only a part of invested capital. Given the realized return on its portfolio, the bank next repays its creditors. While depositors and subordinate debt owners are paid according to the promised interest rates or interest rate schedule, shareholders are entitled to the bank's dividends that are left once the other two types of creditors have been paid. The bank defaults if it is not able to repay depositors, who have priority in return payments. Otherwise the bank continues operating in the next period. The bank also faces a regulatory authority that puts a minimum requirement on the bank's own capital choice. If the

bank's common equity falls below the regulatory level at the end of the period, the intermediary is subject to a penalty. Events that take place in the model are summarized graphically in Figure 1: 


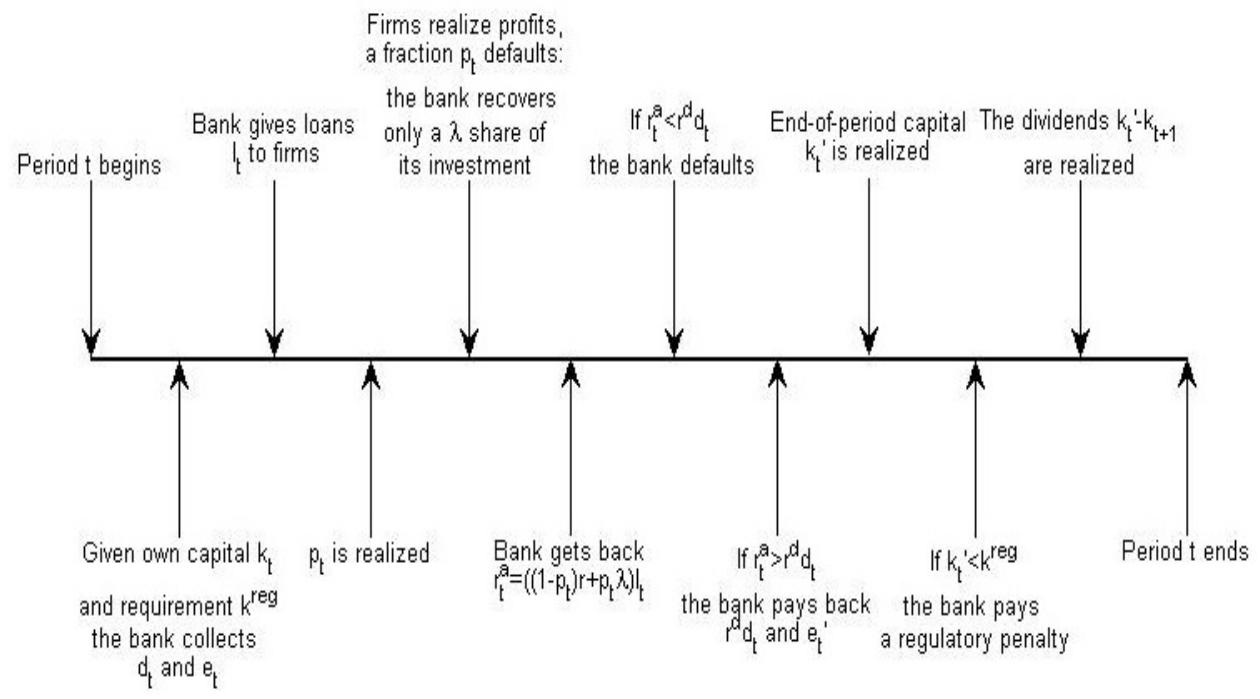

Figure 1: The bank's optimization problem: the period t timeline.

The next two subsections present the representative bank's optimization problem in detail.

\subsection{Balance sheet structure}

Banks serve as capital providers to firms. In particular, assets of the representative bank consist of loans to firms $\left(l_{t}\right)$ that pay a fixed gross interest rate $r$. In each period a fraction $p_{t}$ of loans defaults, in which case the bank is able to recover only a share $\lambda$ of its invested capital. The period $t$ return from a unit of a loan hence equals $\left(1-p_{t}\right) r+p_{t} \lambda$. As in Elizalde and Repullo (2007) we assume that $p_{t}$ is a random variable with the distribution derived from the single risk factor model in Vasicek (2002) with mean $\bar{p}$ (unconditional default probability of a single firm in the portfolio) and correlation coefficient $\rho$ (exposure to the systemic risk). The Vasicek (2002) model is also the theoretical setting used by the Basel Committee to derive both Basel-II and Basel-III capital requirements, which adds realism to our analysis of capital regulations.

The bank finances its intermediation activity from three sources:

- deposits $\left(d_{t}\right)$ that pay a gross interest rate $r_{t}^{d}$,

- subordinate debt $\left(e_{t}\right)$ that pays a gross interest rate $r_{t}^{e}$ (which is conditional on the performance of the bank's assets),

- common equity $\left(k_{t}\right)$ that comes from capital injections from shareholders, who in return receive exclusive rights to the bank's dividends.

All players, i.e. banks, capital holders and firms are risk-neutral and maximize their expected profits from investment decisions. The balance sheet clearing condition implies that $l_{t}=k_{t}+d_{t}+e_{t}$. The structure of the balance sheet is presented in Figure 2: 


\begin{tabular}{c|c} 
Assets & Liabilities \\
\hline loans to firms $l_{t}$ & deposits $d_{t}$ \\
& $\begin{array}{c}\text { subordinate debt } e_{t} \\
\text { common equity } k_{t}\end{array}$
\end{tabular}

Figure 2: The bank's balance sheet

A bank goes bankrupt if the current period return from its activities is lower than the gross return owed to depositors:

$$
\left[\left(1-p_{t}\right) r+p_{t} \lambda\right] l_{t}<r_{t}^{d} d_{t}
$$

In case of a default shareholders and subordinate debt owners lose their all invested capital and the bank stops operating forever. This happens as the bank in our model does not hold any cash (apart from the gross return from its portfolio) it could use to pay its debts. Alternatively, one can think of this closure rule also in terms of the Diamond and Rajan (2009) fire-sales event, where banks do not want to liquidate assets in a situation of a financial distress.

If the bank does not default, the return payments to depositors $\left(d_{t}^{\prime}=r^{d} d_{t}\right)$ are realized. The subordinate debt owners $\left(e_{t}^{\prime}\right)$ are paid back afterwards from the remaining part of the gross return. Finally, conditional on the bank continuing its activity in the next period, dividends are paid to shareholders equal to the excess of own capital over the actual capital chosen at the beginning of the next period: $k_{t}^{\prime}-k_{t+1}$.

Deposits are fully insured by the government and hence depositors are paid back their invested capital by the national insurer if the bank defaults. As their capital is fully insured, the risk-neutral depositors are always paid the risk-free interest rate, which - for simplicity of exposition - is assumed to be fixed and equal $r^{d}$.

The gross rate of return on loans, $r$, is chosen to assure a positive intermediation margin, $\delta>0$, i.e. the difference between the average gross rate of return on the bank's portfolio and the interest paid on deposits:

$$
\delta=(1-\bar{p}) r+\lambda \bar{p}-r^{d}
$$

Because of deposit insurance, depositors do not have incentives to control the portfolio risk taken by the bank and do not require a higher interest rate for a higher default probability. This is not the case for subordinate debt owners, whose payments are conditional on the bank's performance. The interest rate paid on subordinate debt increases with the probability of a bank's default and thus subordinate debt can be viewed as a market disciplining tool: in order to reduce the interest rate on subordinate debt $e_{t}$ the bank will have to increase the amount of own capital to increase its distance to default (lower the probability of a default). Payments to subordinate debt owners are explained in detail in Section 2.4. 


\subsection{Maximization problem}

For simplicity of calculations the period $t$ value of liabilities, $l_{t}$, is normalized to 1 . Each period, given the corresponding interest rates $r, r^{d}, r_{t}^{e}$, the bank's manager chooses $k_{t}$ and $e_{t}$ as fractions of total assets $\left(d_{t}\right.$ then follows from the balance sheet identity: $d_{t}=1-k_{t}-e_{t}$ ) such that the current value $V_{t}$ of its future increments to net worth,is maximized:

$$
V_{t}=E_{t} \sum_{i=0}^{\infty}\left(\frac{1}{r^{k}}\right)^{i} R_{i} n_{t+i}
$$

where $\frac{1}{r^{k}}$ is a discount factor, with $r^{k}$ being the cost of equity, equal to the expected return required by shareholders of the bank. For simplicity it is assumed to be fixed over time. Equity is always more costly than other sources of funds as shareholders face higher uncertainty over returns than other funding providers $\left(r^{k}>r^{d}\right.$ and $\left.r^{k}>r_{t}^{e}\right)$. Next, $n_{t+i}$ stands for the bank's increment in net worth (as a fraction of the bank's assets $l_{t+i}$ ) at the end of period $t+i$, i.e. the difference between the common equity at the end of period $\left(k_{t+i}^{\prime}\right)$ and at the beginning of period $\left(k_{t+i}\right)$.

Normalizing the value of bank's total assets each period to 1 considerably simplifies the optimization problem (3) that has to be solved numerically (see Section 4 for details). In particular, we can treat each period's bank capital decision independently from past values of retained earnings, end-of-period common equity level, etc. It also allows us to avoid considerations of bank capital accumulation over time ${ }^{4}$. The price we pay for those advantages is that, within such setting, we cannot analyze size effects, i.e. the impact of capital regulations on the size of bank's lending activity. Taking $i=0$ it follows that (given $n_{t}=k_{t}^{\prime}-k_{t}$ and after normalizing $l_{t}=1$ ):

$$
k_{t}^{\prime}=\left[\left(1-p_{t}\right) r+p_{t} \lambda\right]-e_{t}^{\prime}-r^{d} d_{t}
$$

After the choice of the liabilities structure in period $t$ has been made, the defaulting fraction of assets, $p_{t}$, is realized and the end-of-period common equity $k_{t}^{\prime}$ is calculated. Given $k_{t}^{\prime}$ the following three cases can be distinguished:

- case I: $\left[\left(1-p_{t}\right) r+p_{t} \lambda\right]>r^{d} d_{t}+r_{t}^{e} e_{t}$

Both depositors and subordinate creditors are paid their gross interest rates $\left(d_{t}^{\prime}=r^{d} d_{t}\right.$ and $e_{t}^{\prime}=r_{t}^{e} e_{t}$ respectively) and the bank continues operating $\left(k_{t}^{\prime}>0\right)$. Shareholders can count on dividends if in addition $k_{t}^{\prime}>k_{t}$ (the size of dividends depends then on the share of $k_{t}^{\prime}$ shareholders want to leave as the common equity for the next period).

- case II: $r^{d} d_{t}<\left[\left(1-p_{t}\right) r+p_{t} \lambda\right]<r^{d} d_{t}+r_{t}^{e} e_{t}$

\footnotetext{
${ }^{4}$ An alternative approach to the internal capital accumulation issue is presented in Gertler and Karadi (2011), where each period a fraction of bankers leaves the market (with their total retained earnings) so that a situation where banks finance their whole lending activity from own funds, thereby bypassing market frictions, never occurs. Modeling the bank's objective function in line with Gertler and Karadi (2011) would not qualitatively change our main results, while significantly increasing computational complexity.
} 
Returns from loans to firms allow the bank to repay depositors (they receive the full amount $r^{d} d_{t}$ ) but are not sufficient to fully repay the subordinate debt owners, in which case subordinate creditors receive the remaining part of returns:

$$
e_{t}^{\prime}=\left[\left(1-p_{t}\right) r+p_{t} \lambda\right]-r^{d} d_{t}
$$

The common equity falls to zero: $k_{t}^{\prime}=0$. Shareholders lose their invested capital, but the bank keeps operating in the next period. As we only consider the liabilities structure choice of the bank (which is made each period independently of previous periods) and do not analyze the size of the bank's lending activity, we assume that shareholders recapitalize the bank each time its capital falls to zero.

- case III: $\left[\left(1-p_{t}\right) r+p_{t} \lambda\right]<r^{d} d_{t}$

The bank is not able to repay neither subordinate creditors nor owners of deposits, in which case $k_{t}^{\prime}<0$, the bank is closed down by the deposit insurance agency so the bank stops operating forever, and shareholders and subordinate debt owners lose their capital.

The term $R_{i}$ in the objective function (3) represents the probability that the bank will continue to be allowed operating in period $i$ given that it has survived all preceding periods, and thus equals for all $i \geq 1$ ):

$$
R_{i}=\prod_{s=1}^{i} \operatorname{Pr}\left(\left(1-p_{t+i-s}\right) r+p_{t+i-s} \lambda>r^{d} d_{t+i-s}\right)
$$

Summarizing all three cases, payments to subordinate creditors are equal:

$$
e_{t}^{\prime}=\left\{\begin{array}{cc}
\min \left\{\left(1-p_{t}\right) r+p_{t} \lambda-r^{d} d_{t}, r_{t}^{e} e_{t}\right\} & \text { if no default } \\
0 & \text { if default }
\end{array}\right.
$$

where the interest rate on subordinate debt, $r_{t}^{e}$, satisfies the no-arbitrage condition between deposits and subordinate debt:

$$
E_{t}\left[\min \left\{r_{t}^{e} e_{t},\left(1-p_{t}\right) r+p_{t} \lambda-r^{d} d_{t}\right\} \mid\left(1-p_{t}\right) r+p_{t} \lambda>r^{d} d_{t}\right] \times \operatorname{Pr}\left(\left(1-p_{t}\right) r+p_{t} \lambda>r^{d} d_{t}\right)=r^{d} e_{t}
$$

Subordinate debt owners require an interest rate that will alwaysbe higher than the interest rate on deposits for two reaasons: first to compensate for possibly lower payments even when the bank does not default (the first term on the LHS of equation (5)). And second, they also recognize that the bank can default and demand a correspondingly higher interest (the second term on the LHS of equation (5)). Based on (5) the subordinate debt interest rate can be derived numerically for each pair of deposits and subordinate debt levels. 


\subsection{Moral hazard problems}

We introduce a moral hazard friction between the bank's manager and its creditors, which leads to an endogenous funding structure (leverage constraint). Following Gertler and Karadi (2011), we assume that each period the bank's manager is able to embezzle a fraction of its assets, $\theta_{t}\left(c_{t}\right)$, that is a function increasing in the ratio of subordinate debt over the bank's total assets: $c_{t}=\frac{e_{t}}{l_{t}}$. One possible justification of such specification is that by giving less discretion over payoffs, short-term deposits yield more control over the bank's managers than subordinate debt does.

Capital holders correctly internalize the possibility of a fraud and in order to invest their funds with the bank they impose a leverage constraint on the bank such that:

$$
V_{t} \geq \theta_{t}\left(c_{t}\right) l_{t}
$$

Condition (6) says that creditors will only supply funds to the bank if the manager has no incentive to embezzle the bank's assets: this happens when the bank's continuation value at period $t$ exceeds or equals the current value of assets that might be embezzled (the "walk-away" value). When this constraint holds, the manager always chooses to continue bank's operations over diversion of funds. For the baseline model specification we follow Gertler, Kiyotaki and Queralto (2011) and assume the following form of $\theta_{t}\left(c_{t}\right)$ :

$$
\theta_{t}\left(c_{t}\right)=\varepsilon c_{t}+\frac{\kappa}{2} c_{t}^{2}
$$

which means that the embezzled fraction of assets is a convex function of the subordinate debt's ratio over the bank's assets, with a minimum at $c_{t}=0$ (no subordinate debt). We proxy the impact of subordinate debt on corporate governance problems by imposing $\frac{d \theta_{t}}{d c_{t}}=\varepsilon+\kappa c_{t}>0$, so that the fraction of funds that can be diverted (and thus the attractiveness of doing so) is increasing with the amount of subordinate debt chosen.

\section{Economic, regulatory, and actual capital}

The main objective of this study is to analyze differences between capital ratios chosen by banks in absence of capital regulations and capital ratios preferred once the minimum capital requirements are introduced. In this section we hence present a brief description of different concepts of capital to be investigated within the theoretical framework constructed in Section 2.

\subsection{Concepts of optimality}

The central analysis of this study is limited to the following concepts of capital.

Economic capital is the capital level that would be chosen by the bank in absence of capital requirements. It is a function of the set of parameters: $\left\{\bar{p}, \lambda, \rho, r^{d}, r^{k}, r, \varepsilon, \kappa\right\}^{5}$. In absence of regulations the bank's

\footnotetext{
${ }^{5}$ The capital chosen is also a function of $r_{t}^{e}$, which in turn is a function of other parameters: see eq. (5).
} 
optimization problem is represented by the following Bellman equation:

$$
\begin{aligned}
V_{t}=\max _{k_{t}, e_{t} \in[0,1]}\left[-k_{t}+\frac{1}{r^{k}}\left(E_{t}[\max \{\right.\right. & {\left.\left.\left[\left(1-p_{t}\right) r+p_{t} \lambda\right]-r^{d} d_{t}-\min \left\{\left[\left(1-p_{t}\right) r+p_{t} \lambda\right]-r^{d} d_{t}, r_{t}^{e} e_{t}\right\}, 0\right\}\right]+ } \\
+ & \left.\left.P\left(\left[\left(1-p_{t}\right) r+p_{t} \lambda\right]>r^{d} d_{t}\right) V_{t+1}\right)\right]
\end{aligned}
$$

subject to the incentive constraint (6) and the balance sheet clearing condition $\left(d_{t}+k_{t}+e_{t}=1\right)$. The bank's current period value $V_{t}$ is maximized w.r.t. the liabilities structure and it consists of three parts: the common equity brought in at the beginning of period by the shareholders (with a negative sign, as the bank's objective is to maximize the difference between the end-of period and the beginning-of-period capital), the discounted expected value of end-of-period profits and the discounted expected value of continuing the bank's operations in the next period $\left(V_{t+1}\right)$.

Regulatory capital corresponds to the minimum capital ratio imposed on banks by the financial regulator. We focus on the common equity requirement, denoted by $k^{r e g}$, which is modeled to resemble the Basel Committee provisions on Tier 1 capital. Thus, it is risk-sensitive and calculated for a given confidence level. Under Basel II the confidence level is equal to $\alpha=0.999$, meaning that a bank is expected to not be able to cover its losses and default at most once every thousand years. More precisely, if $p^{*}$ denotes the threshold fraction of the defaulting firms in the bank's portfolio for which $\operatorname{Pr}\left(p_{t} \leq p^{*}\right)=0.999$, then $k^{r e g}$ is set to satisfy $k^{r e g}=\phi(1-\lambda) p^{*}$. This in turn is equivalent to setting $k^{r e g}=\phi(1-\lambda) F^{-1}(0.999)$, where $F\left(p_{t}\right)$ is the large homogenous portfolio approximation of the loss rate distribution function derived in Vasicek $(2002)^{6}$ :

$$
F\left(p_{t}\right)=\Phi\left(\frac{\sqrt{1-\rho} \Phi^{-1}\left(p_{t}\right)-\Phi^{-1}(\bar{p})}{\sqrt{\rho}}\right)
$$

In the above formula $\rho$ is the systemic risk exposure, $\bar{p}$ is the individual (unconditional) probability of a loan default equal for all loans in the portfolio and $\Phi(\cdot)$ is the cdf of the standard normal distribution. The multiplier $\phi \in[0,1]$ represents the fact that under Basel Accords only a fraction ( $\phi=0.5$ for Basel II) of the total capital minimum has to be in the form of common equity. The term $1-\lambda$ represents the size of losses that occur due to defaults in the bank's portfolio and that have to be covered.

It follows that regulatory capital $k^{r e g}$ is a function of the set of parameters: $\{\lambda, \bar{p}, \rho, \alpha, \phi\}$. Finally, in our model capital requirements affect the capital ratio chosen at the beginning of each period, independently of the realized defaulting fraction of assets, $p_{t}$, so the capital ratio chosen at the beginning of the period may differ from the one that is realized at the end of the period.

Actual capital is the capital (ratio) chosen by the bank as a result of maximizing (8) subject to the incentive constraint (6), the balance sheet clearing condition and the minimum capital requirement:

$$
k_{t} \geqslant k^{r e g}
$$

\footnotetext{
${ }^{6}$ As in our model realizations of $p_{t}$ are also drawn from the Vasicek (2002) distribution, we implicitly assume that the regulator's model used to calculate minimum requirements correctly internalizes the true process governing the random variable, $p_{t}$.
} 
We argue there are several rationales for the actual capital ratio to be different from the regulatory minimum. The first reason for positive excess capital $\left(k_{t}>k^{r e g}\right)$ is stressed in Elizalde and Repullo (2007): for sufficiently low values of the confidence level, $\alpha$, the regulatory minimum will be below the economic capital ratio preferred by the bank in absence of regulations. In that case actual capital will be set at the level of economic (i.e. unconstrained) capital. It follows then that the required capital ratios do not have any impact on bank's capital choices if they are below actually observed ratios in the ER framework. On the other hand, once capital requirements exceed the economic capital ratio and become binding, the bank will always choose its actual capital to be equal to the regulatory minimum, implying zero excess capital in the Elizalde and Repullo (2007) setting.

But banks cannot control capital levels at every point in time and so they may incur regulatory penalties even when actual capital levels are set ex-ante to comply with regulatory minima, for example if (in our setup) loan defaults are higher than anticipated. Therefore, in fear of possible regulatory penalties, banks may choose to keep excess capital over the regulatory minimum for all levels of risk in the economy and also for low confidence levels.

This is exactly what is happening in our model: regulatory penalties for not meeting capital requirements ex-post, which we introduce in Section 3.2, form an additional motive for banks to keep extra capital above the regulatory ratio. The minimum capital requirement condition combined with the ex-post violation penalty imply that our constraint (9) is then imposed (in expected value terms) on the end-of-period capital, i.e. takes the form: $k_{t}^{\prime} \geqslant k^{r e g}$, rather than on beginning-of-period capital. This makes the problem of the bank more realistic as the intermediary can never be sure with probability 1 whether it complies with the capital requirement at the end of the period (which is after the exogenous portfolio default rate, $p_{t}$, is realized). We will show that in our setup raising capital requirements will have an impact on actual capital held (and thus also on overall credit conditions) by the bank even when actual capital already exceeds both the old and the new capital requirements, contrary to what happens in the Elizalde and Repullo (2007) model. Our framework also allows for a richer analysis of the Basel regulations; in particular we can analyse the impact of the so-called countercyclical buffer included in the Basel-III proposals (see Section 4.3).

\subsection{Regulatory penalties}

In practice most banks hold capital ratios in excess of the minimum required by financial regulators. Possible explanations for this phenomenon that are recognized in the economic literature include capital adjustment costs, negative market signaling related to additional equity issuance (Myers and Majluf (1984)), also leading to adjustment costs; and finally regulatory fines and compulsory recapitalizations, which we focus on. The key idea behind the impact of regulatory penalties on capital buffers is that as banks have to satisfy capital regulations on an ongoing basis, additional capital lowers the probability of falling under the regulatory minimum and bearing costs following such event.

Under current Basel regulations the measures suggested in case of a capital requirement violation include intensified monitoring of the bank, management control, restrictions on paying out dividends , compulsory raising of additional capital (paragraphs 759-760, Basel Committee (2006)). These penalties do not exist only on paper. Based on the Capital Requirements Directive (which implements the Basel II framework in 
the EU) the European Banking Authority has undertaken the abovementioned measures e.g. 38 times in Spain and 35 times in Ireland in year 2010 alone. In September 2009 the Fed ordered the AmericanWest Bank to halt its dividend payments and to submit a plan to raise additional capital in response to the bank's Tier 1 capital falling to a level of $3.3 \% .^{7}$

To incorporate regulatory penalties and their impact on banks' capital decisions in the theoretical setting of Section 2, we impose a penalty - in form of a forced recapitalization - for not meeting capital requirements at the end of the period. In our model dividends can only be paid out when the end-of-period capital exceeds the minimum ratio required, so introducing additional constraints on dividend payments as a regulatory penalty for non-compliance with capital requirements is not meaningful within our setting. Also, because we do not consider agency problems between shareholders and bank managers, temporary control over bank's management has no impact within our framework and hence is not considered as a regulatory penalty measure. Finally, intensified bank monitoring can be viewed as imposing extra costs on the bank in our model and is thus similar to an ex-post fine.

Below we present two alternative specifications of the regulatory penalty that we introduced in the theoretical setting from Section 2. Both take the form of a forced recapitalization imposed by the regulator on a non-complying bank, both are temporary and proportional to the size of the minimum requirement violation. We would like to stress that these features of our ex-post violation penalties stay in opposition to a standard way of modeling regulatory penalties present in the literature, i.e. via fixed ex-post fines. While a fine is a more severe penalty than a forced recapitalization and thus gives even stronger incentives to hold positive excess capital to a bank, it is difficult to imagine that in reality a regulator would punish an already weakly capitalized bank by taking even more capital from it and hence worsening its financial stability even further. Of course, we recognize that in real world compulsory raising extra common equity in a situation of financial distress can be also very problematic (for sure very costly) for a bank ${ }^{8}$. On the other hand, however, such compulsory recapitalization should increase bank's financial soundness at least in the long-term and, all in all, to prevent banks from holding too low actual capital ratios, an ex-post penalty should actually be painful for the bank.

\subsubsection{Forced recapitalization}

In this setup, when a bank's common equity to total assets ratio falls below the regulatory minimum at the end of current period, the minimum capital requirement for next period for this bank is increased. This forced recapitalization takes a form of an additional condition on the common equity ratio:

$$
k_{t}^{\prime}<k^{r e g} \Rightarrow k_{t+1} \geqslant k^{r e g}+\left(k^{r e g}-k_{t}^{\prime}\right)
$$

where the temporary increase in the capital requirement is proportional to the size of the current period violation. Moreover, if in period $t+1$ the penalized bank does not comply with the new higher capital

\footnotetext{
${ }^{7}$ Source: eba.europa.eu, federalreserve.gov.

${ }^{8}$ Note that we do not analyze the means by which banks adjust their actual capital ratios: while such adjustments can take place by raising new capital, it is more plausible (and empirically confirmed: see e.g. Adrian and Shin, 2010) that banks will choose a cheaper solution and simply reduce the size of lending in response to an increase in minimum capital requirements.
} 
minimum, the compulsory requirement will be raised further in period $t+2$, and so on. ${ }^{9}$

For the bank, the direct costs of the forced recapitalization are proportional to the difference between the cost of common equity and other sources of funds (since now a higher amount of common equity has to be held instead of cheaper deposits or subordinate debt). The Bellman equation (8) takes the form:

$$
\begin{gathered}
V_{t}=\max _{k_{t}, e_{t} \in[0,1]}\left[-k_{t}+\frac{1}{r^{k}}\left(E_{t}\left[\max \left\{\left[\left(1-p_{t}\right) r+p_{t} \lambda\right]-r^{d} d_{t}-\min \left\{\left[\left(1-p_{t}\right) r+p_{t} \lambda\right]-r^{d} d_{t}, r_{t}^{e} e_{t}\right\}, 0\right\}\right]-\right.\right. \\
\left.\left.-\underline{R E C_{t}}+P\left(\left[\left(1-p_{t}\right) r+p_{t} \lambda\right]>r^{d} d_{t}\right) V_{t+1}\right)\right]
\end{gathered}
$$

subject to the incentive constraint (6), the balance sheet clearing condition, the capital requirement (9), and where the additional term $R E C_{t}$ represents the expected costs of non-compliance and is equal to:

$$
R E C_{t}=\operatorname{Pr}\left(0 \leq k_{t}^{\prime}<k^{r e g}\right) \frac{1}{r^{k}} E_{t}\left[\left(r^{k}-r^{d}\right)\left(k^{r e g}-k_{t}^{\prime}\right) \mid 0 \leq k_{t}^{\prime} \leq k^{r e g}\right]
$$

We measure the opportunity cost of additional capital that bank has to hold because of the temporarily higher minimum requirement by taking the difference between the cost of capital, $r^{k}$, and deposits interest rate, $r^{d}$, as in expectations the cost of deposits and subordinate debt is the same as a consequence of our risk neutrality assumptions. The discount factor $\frac{1}{r^{k}}$ is used as the loss is incurred in the next period, $t+1$.

\subsubsection{Forced recapitalization with a "market" penalty}

In an alternative model version we keep the same form of the ex-post violation penalty (increased minimum capital requirement for the next period) but consider another specification of the costs related to the forced recapitalization:

$$
R E C_{t}=\operatorname{Pr}\left(0 \leq k_{t}^{\prime}<k^{r e g}\right) \frac{1}{r^{k}}\left[\sqrt{\left(r^{k}-r^{d}\right)\left(k^{r e g}-E_{t}\left(k_{t}^{\prime} \mid 0 \leq k_{t}^{\prime}<k^{r e g}\right)\right.}\right]
$$

Using the squared root of the capital requirement violation implies a higher than one-to-one penalty ${ }^{10}$. The formula chosen also implies a penalty cost that is concave in the extent of non-compliance (shortfall with respect to the required capital ratio), i.e. the marginal penalty is decreasing in the size of violation. The primary motivation for this specification is that it is a simple way of modeling additional costs of violating capital requirements, for example related to the negative signal about the bank's financial condition that such violations give to the market. In addition, it can be expected that, after passing the minimum threshold, further falls in the capital ratio below the regulatory minimum do matter, but increasingly less so, as they do not possess the same informational value as passing the minimum itself; hence the choice of a concave cost function.

Taking a squared root of the penalty should be treated as a way to account for the additional "market" penalty for not meeting capital requirements that is beyond the control of the regulatory authority but does

\footnotetext{
${ }^{9}$ This makes sure that temporarily higher capital requirements also bite for banks that already choose capital levels above the regulatory minimum.

${ }^{10} \mathrm{As}$ all the violations are in terms of fractions, squaring them would lower the prescribed penalty significantly.
} 
have an impact on the bank. The rationale for this alternative penalty specification is based on the recently expressed opinion of the the World Savings Bank Institute ${ }^{11}$ on the proposal of a countercyclical buffer under Basel III: "We remain highly skeptical of the fact that banks would be allowed, by the market, the rating agencies or even their supervisors, to actually use their buffer when the economic situation deteriorates. We recall the recent experience in the latest crisis when market expectations (and also regulators' demands at that time) forbid banks to reduce their capital base. On the contrary, they had to boost it immediately." (WSBI (2010)). This view of WSBI, besides expressing concerns over feasibility of the countercyclical buffer, points at existence of other than regulatory, i.e. "market" or "reputational", penalties for not meeting capital requirements, and justifies considering penalty costs in the form of (12).

\subsection{Numerical methods and calibration}

Numerical Approach In solving the bank's constrained optimization problem (3) we followed the dynamic programming representation of the problem. The desired policy functions for capital and subordinate debt are continuous and compact-valued correspondences, so by the Contraction Mapping Theorem (See Theorem 3.2 in Lucas, Stokey and Prescott (1989)) the infinite horizon dynamic programming problem given by equation (10) has a unique solution.

To find that solution we used the Value Function Iteration method with a grid search over a constrained range of control variables. In this iterative procedure the Bellman equation (10), subject to (A) the incentive constraint (6), (B) the balance sheet clearing condition, and (C) - if applicable - the capital requirement (9), was maximized until convergence. The basic numerical algorithm and other numerical choices are elaborated upon in Appendices 7A-C.

Calibration The European Parliament Directive 2006/48/EC implementing Basel-III provisions in the EU introduced a harmonized reporting framework (Common Reporting Procedures, COREP) for reporting of capital ratios. Under these new rules the basic reporting frequency was set at a maximum of 3 months (starting from 2012). Also, banks typically publish their financial statements on a monthly or quarterly basis. Therefore we decided to calibrate our model parameters on the assumption that one period in the model equals a 3 -month time span.

In most cases annual values are reported in the literature as estimates corresponding to our model parameters, so we decompose these annual values into quarterly equivalents. For example, we obtain quarterly gross interest rates by applying a simple compounding interest rule (i.e. the annual gross interest rate is equal to the quarterly rate to the power four). The quarterly unconditional portfolio default probability is obtained by applying a simple rule of thumb and dividing the corresponding annual value by four. However, under Basel provisions the capital minimum requirements are calculated to cover one-year-ahead loan losses with a given probability. Therefore, when calculating the minimum requirements, we use the Basel-II formulas for corporate exposures of one-year maturity (and thus apply one year default probabilities). In addition, the temporarily higher capital requirement imposed in case of a capital requirements' violation is also assumed to hold for a one-year time span.

\footnotetext{
${ }^{11}$ The WSBI is a global institution representing interests of savings and retail banks.
} 
The real (gross) cost of common equity is set to 1.06 on annualized basis, in line with the calibration in Elizalde and Repullo (2007). This value comes from the estimates of the average Tier- 1 capital cost over the period 2002-2009 in six OECD countries in King (2009). It is also in line with the estimated average Tier-1 capital cost for G-10 countries over the period 1993-2001 in Maccario et al. (2002). The gross interest rate on deposits is set to 1.01 annually (in real terms) and is assumed to equal the risk-free rate. By (2) the average return on bank's assets is equal to the risk-free rate plus the intermediation margin. The latter is set to 0.01, in line with Elizalde and Repullo (2007) and Repullo and Suarez (2012).

We set the steady state subordinate debt level, $\bar{e}$, to to match - for the case of no capital requirements the average Tier-2 capital ratio before Basel-II regulations were introduced. In particular, we calibrated the moral hazard function to match (A) value of zero at the function minimizing point $(\theta(0)=0)$ and $(B)$ a $4 \%$ level subordinate debt in the absence of capital requirements. This is in line with the results of Sironi (2001) who obtained the average share of fixed maturity subordinate debt (SND) in total liabilities of approximately $2 \%$ in the US, European Union and Switzerland at the end of 1999. As according to Basel Committee the long-term subordinate debt cannot exceed $50 \%$ of the maximum total Tier 2 capital level allowed, we obtain the value of $4 \%$ for Tier 2 level.

For more details on the calibration choices we refer to Appendix 7C. A short summary of all calibration choices is given below in Table 1 .

\begin{tabular}{|c|c|c|}
\hline Parameter & Values & Comments \\
\hline \hline $\bar{p}$ & 0.02 & Basel II for corporate exposures \\
\hline$\alpha$ & 0.999 & the Basel II reference level \\
\hline$\lambda$ & 0.55 & Basel II provisions for unsecured corporate exposures \\
\hline$\delta$ & 0.01 & annual intermediation margin (Elizalde and Repullo, 2007) \\
\hline$r$ & 1.0296 & set to match a 0.01 margin over 1.01 annual risk-free interest rate \\
\hline$\rho$ & 0.164 & Basel II provisions for corporate and and bank exposures \\
\hline$\phi$ & 0.5 & Basel II min. share of Tier 1 capital in the total capital requirement \\
\hline$r^{d}$ & 1.01 & gross interest on deposits equal to the risk-free rate (full insurance) \\
\hline$r^{k}$ & 1.06 & King (2009); Maccario et al. (2002) \\
\hline$r^{e}$ & varying & numerically solved for from the equation (5) \\
\hline$\varepsilon$ & -53 & moral hazard function parameters calibrated to match $\bar{e}=0.04$ \\
& in absence of capital requirements (Sironi, 2001) \\
\hline$\kappa$ & 2809 &
\end{tabular}

Table 1: Key parameter values used in numerical calculations.

\section{Results}

In this section we show the main results on actual capital holdings in response to (changes in) a variety of environment variables. In particular, we investigate the responses of different capital concepts (i.e. economic, actual, and regulatory capital) to changes in the exogenous portfolio default rate, $\bar{p}$, and the confidence level, $\alpha$, used by the regulator to set its capital requirements (Sections 4.1-4.2). In subsequent subsections we 
specifically analyze the impact of the countercyclical buffer envisaged under Basel III on the procyclicality of the system (Section 4.3), and of the European Commission "bail-in" proposal on Tier-2 capital (Section 4.4).

\subsection{Capital, risk and regulatory tightness}

We begin with an analysis of the impact of regulatory tightening. In the upper panel of Figure 3 we show the response of various capital concepts to increases in $\alpha$, the confidence level regulators require when setting minimum capital ratios (where $\alpha$ varies from 0.99 to 0.999), keeping other parameters fixed at their baseline levels reported in Table 1. Of course, the desired capital when ignoring all restrictions (economic capital) is not affected by changes in $\alpha$ at all: it is a flat line at $0.5 \%$, which is also the minimum value of common equity allowed in our grid ${ }^{12}$. Regulatory capital requirements do respond, given the way they are set: the solid line indicates that as $\alpha$ increases over the range considered, the regulatory capital requirement increases from $2.5 \%$ to almost double that level (4.4\%). And when an ex-post minimum requirement violation does not lead to any penalties, actual (i.e. constrained optimal) capital stays right at the required level, since the latter is above the economic capital ratio over the entire range considered. This is the standard view expressed in the literature: capital is either at its economic level or at the required ratio, whichever of the two is higher.

However, that changes when penalties for ex-post requirement violation are introduced. Simply being forced to recapitalize up until the new required ratio already introduces a wedge between the actual capital and the required capital ratio, which however is very small and hence almost invisible in the upper panel of Figure 3. But the stronger "recapitalization plus market reputation" penalty leads to a substantial wedge. This result brings the model behavior substantially closer to empirically observed relationships, and has strong policy implications: even when actual capital is significantly above the ratios required by the regulator, raising regulatory capital requirements will nevertheless have a significant impact on banks' desired capital holdings. This is clearly of crucial importance for an analysis of the (macro)economic consequences of tightening capital standards.

The bottom panel of Figure 3 shows that for higher unconditional portfolio default rates (here for $\bar{p}=4 \%$ ) the actual capital ratio also for the (less severe) forced recapitalization penalty is visibly higher than the regulatory requirement. Moreover, the economic capital ratio is no longer chosen at the minimum level allowed by the grid (it increases with $\bar{p}$ ).

\footnotetext{
${ }^{12}$ Economic capital is chosen at a higher level once the unconditional portfolio default risk, $\bar{p}$, representing the level of risk in the economy, increases. For example, for $\bar{p}=0.04$ the economic capital is set at $0.8 \%$ (bottom panel of Figure 3 ). However, we obtain rather low values of economic capital in general. This happens as subordinate debt, in absence of any direct default costs, substittes out common equity. In particular, because of our risk neutrality assumption, the spreads between subordinate debt return rates and the risk-free rate are an exact one-to-one mapping from the bank's portfolio unconditional default probabilities. However, it is widely recognized in the literature that default risk alone cannot explain the empirically observed interest rate spreads (Huang and Huang (2003)), which are much higher than theoretical models on corporate defaultable bonds would suggest. As a result of the neutrality assumption, our subordinate debt interest rates are thus relatively modest, which explains the strict preference of bank managers towards subordinate debt over common equity in the model with no capital regulations (i.e. low economic capital levels).
} 

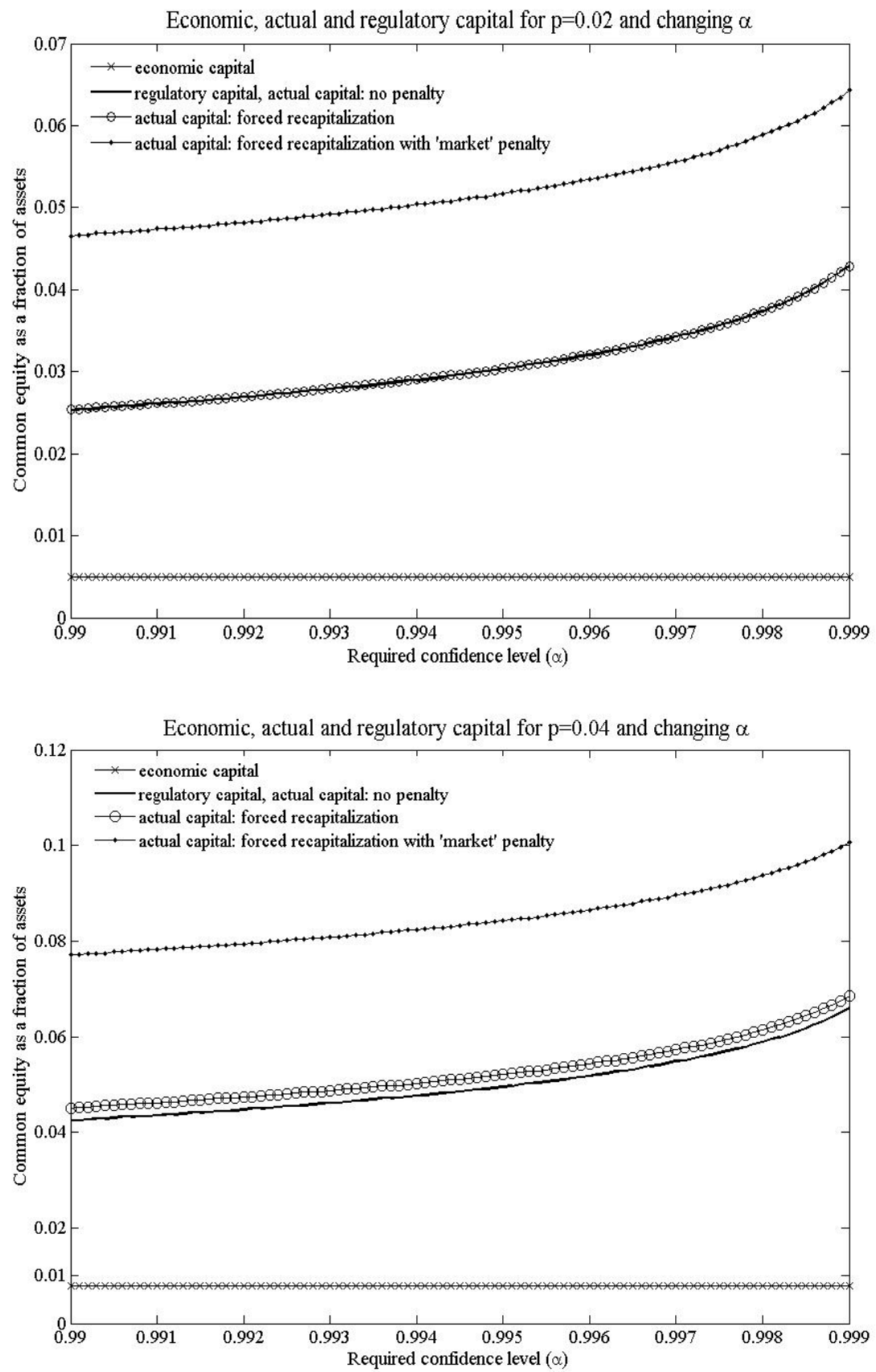

Figure 3: Economic, actual and regulatory capital levels for $\bar{p}=0.02$ and changing $\alpha$, for different model specifications.

Consider next the impact of changes in the (corporate) default rate $\bar{p}$ (Figure 4 below), keeping $\alpha$ fixed. Note that increases in $\bar{p}$ also imply an increase in risk: in the range of values considered here, the 
variance $\bar{p}(1-\bar{p})$ is a rising function of $\bar{p}$. As one could have expected, for very low levels of risk, the economic capital ratios shrink to very low values (upper panel of Figure 4) but rise more than eightfold as the default probability $\bar{p}$ goes up from 1 to $10 \%$, with a commensurate rise in the variance $\bar{p}(1-\bar{p})$. As a result, regulatory capital again exceeds its economic counterpart for all levels of the unconditional default probability considered (for economic capital to exceed the regulatory level, $\alpha$ needs to be at the low end of the range considered here, and $\bar{p}$ at the high end). And of course, the model without ex-post violation penalties again sets actual capital equal to regulatory capital under these circumstances.

Introducing ex-post violation penalties changes the picture entirely. For very low levels of the default risk the actual capital ratio is constrained by the regulatory requirement, but for $\bar{p}$ levels of $2 \%$ and higher banks will choose higher capital ratios than required even if the ex-post penalty consists of just the forced recapitalization. For the higher penalty - that includes a proxy for market reputation penalties - actual capital is chosen substantially higher than the regulatory ratios for all default probability values considered, and increasingly so as $\bar{p}$ rises (bottom panel, Figure 4 ).

Most importantly, for both penalty cost forms, actual capital grows more than the regulatory capital with the riskiness of the portfolio. In other words, the excess capital held by banks is positively correlated with the level of the risk. This happens, as the probability of violating minimum capital requirements increases in $\bar{p}$ : while regulatory requirements rise with the risk in the economy, the expected returns of the bank do not increase (the interest rate on bank's portfolio adjusts to match the fixed intermediation margin of 0.01). Of course, at the same time a higher share of common equity in the bank's liabilities reduces the return payments to bank's creditors and hence protects it from both default as well as requirement violation. Nevertheless, it follows from the numerical results that the bank has to increase its actual capital by more than the rise in the minimum capital requirement to counteract the higher probability of violating the new requirement.

This result has an important implication: with ex-post violation penalties, the risk-based capital regulations are even more pro-cyclical (in the sense of exacerbating business cycle fluctuations) than it would result from the changes in the level of $k^{r e g}$ along the business cycle only ${ }^{13}$. The macroeconomic implications of capital buffers moving countercyclically (up when the cycle goes down) are straightforward to see: an increase in the bank's excess capital is normally associated with shrinking lending to the private sector, which has further contractionary effects on the economy ${ }^{14}$.

These results are also in line with empirical evidence: Saurina et al. (2004), using Spanish panel data, show that the capital buffers held by Spanish banks in years 1986-2000 were negatively correlated with the GDP growth rate. Stolz and Wedow (2005) confirm the result of countercyclical capital buffers for German banks over the period 1993-2003.

\footnotetext{
${ }^{13}$ We reasonably assume that the level of risk and the default probability are negatively correlated with GDP over the cycle (i.e. that recessions correspond to higher values for $\bar{p}$ ), which is confirmed empirically, see for example Altman et al. (2005).

${ }^{14}$ Furfine (2001) shows that the introduction of Basel-I regulations, while raising the actual capital levels held by banks, played also a significant role in the dramatic fall of commercial credit (known as credit crunch) in the early 1990s.
} 

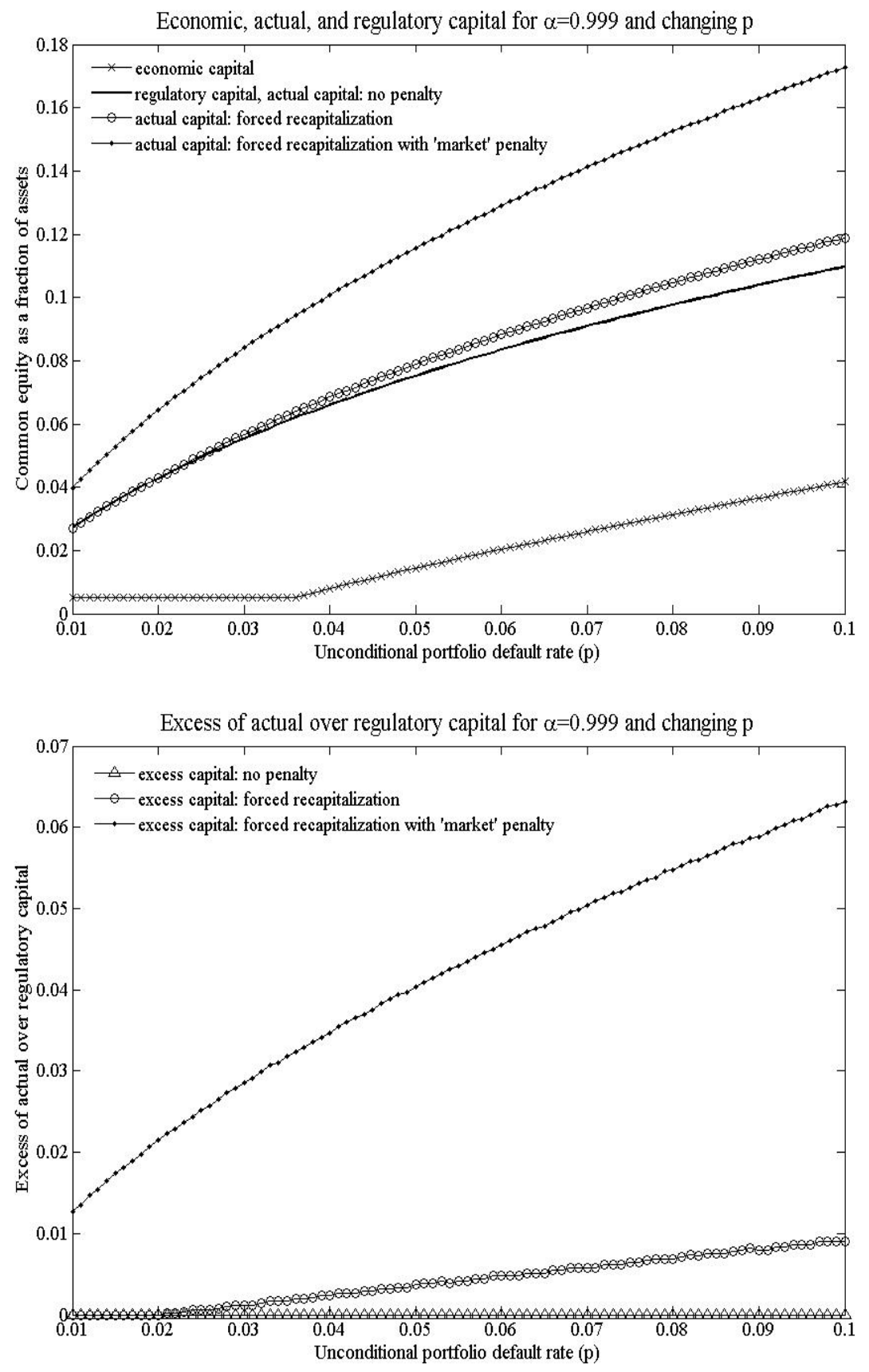

Figure 4: Economic, actual and regulatory capital for changing levels of $\bar{p}$ and $\alpha=0.999$, for different model specifications.

To facilitate comparison with the empirical literature, Table 2 summarizes the results in numbers, under 
two alternative penalty settings and for different levels of $\bar{p}$, keeping $\alpha$ on the reference level of Basel-II provisions, $\alpha=0.999$.

\begin{tabular}{|c|c|c|c|c|c|c|}
\hline $\bar{p}$ & 0.01 & 0.02 & 0.04 & 0.06 & 0.08 & 0.1 \\
\hline & \multicolumn{7}{|c|}{ Penalty (11) } \\
\hline \hline regulatory capital $k^{r e g}(\mathrm{~A})$ & 2.71 & 4.28 & 6.61 & 8.35 & 9.78 & 10.97 \\
\hline actual capital $(\mathrm{B})$ & 2.71 & 4.28 & 6.65 & 8.83 & 10.46 & 11.88 \\
\hline excess capital (B-A) & 0 & 0 & 0.04 & 0.48 & 0.68 & 0.91 \\
\hline \multicolumn{7}{|c|}{ Penalty (12) } \\
\hline regulatory capital $k^{\text {reg }}(\mathrm{A})$ & 2.71 & 4.28 & 6.61 & 8.35 & 9.78 & 10.97 \\
\hline actual capital (B) & 3.98 & 6.43 & 10.07 & 12.91 & 15.26 & 17.29 \\
\hline excess capital (B-A) & 1.27 & 2.15 & 3.46 & 4.56 & 5.48 & 6.32 \\
\hline
\end{tabular}

Table 2: Regulatory, actual and excess capital for two penalty specifications (as \% of total assets).

Again, one can see that the forced recapitalization penalty yields capital buffers growing in the level of risk in the economy but of a relatively small size (small excess capital levels). Incorporating "market" or "reputational" consequences of violating capital requirements increases the buffers significantly. The reported excess capital levels for the latter penalty specification are in line with the empirical average capital buffers calculated by Jokipii and Milne (2008) for a range of European countries.

\subsection{Responses to changes in other parameters}

To asssess the robustness of our results, we also check the responses of different capital concepts to changes in other parameters of the model. Responses to shifts in the recoverable fraction of invested capital in case of distress, $\lambda$, the cost of equity, $r^{k}$, and in the intermediation margin, $\delta$, are presented in Figures 6-7 in Appendix 7D. These sensitivity checks yield predictable results: for example a higher recovery rate in case of corporate distress (higher $\lambda$ ) lowers the value at risk, leading to a commensurate fall in expected losses. As a result all concepts of capital decline, as does the gap between them. In particular the capital buffer held in the case of reputational penalties (on the top of the recapitalization requirement) falls by almost a half compared to the $\lambda=0$ case. A higher intermediation margin, $\delta$, acts as buffer and so leads to lower capital buffer choices. Finally, increasing the cost of common equity shifts the preferences of the bank towards subordinate debt and deposits.

\subsection{Ex-post penalties, the pro-cyclicality of capital requirements and the coun- tercyclical buffer of Basel III}

\subsubsection{Basel III: what will change?}

According to the amendments to capital regulations to be implemented under Basel III, the amount of regulatory capital will increase significantly as a share of risk-weighted assets. But the structure of minimum requirements will change too, with the proportion of Tier-1 capital to go up significantly. One step in both directions (more and higher quality capital) is the creation of a compulsory conservation buffer of $2.5 \%$ 
of RWA, that can be built up from Tier-1-type capital only ${ }^{15}$. This will be equivalent to a rise of the overall capital requirement to $10.5 \%$ of RWA with a simultaneous increase of the Tier-1 capital share to approximately 8.4 percentage points (after including the additional increase in the share of Tier-1 capital in the base $8 \%$ requirement to 6 percentage points). Basel III also introduces a so-called countercyclical capital buffer of up to $2.5 \%$ of RWA. It is expected to be implemented by mandating increases in the equity-to-assets ratio (of Tier-1 capital only) during periods of excessive credit growth and allowing drawing it down during periods of economic slack. In this way, the total capital requirement will reach $13 \%$ during expansions but will fall gradually to $10.5 \%$ of RWA during recessions. The introduction of this countercyclical element comes down to using a a family of risk functions, instead of a single risk function only (as under Basel II), to address the widely criticized pro-cyclical character of Basel-II capital provisions (Kashyap and Stein (2004)).

The above Basel-III provisions are about to be phased in, but the existing assessments of their expected effects in the literature so far have been based on mechanical application of simple cost-benefit accounting exercises, without any explicit consideration of potential behavioral responses by the banks (e.g. Cournede and Slovik (2011)). Yet such responses (appearing as changes in capital buffers held above regulatory capital ratios) may have a significant impact on the likely macroeconomic consequences of Basel III. We therefore use the theoretical setup developed in Sections 2 and 3 to compare what we can expect banks' actual capital ratios to be under alternatively Basel-II and Basel-III regulations. We also extend the analysis to assess the expected impact of the countercyclical buffer that is a part of Basel-III proposals.

But our model as set up in Section 2 is inappropriate for an analysis of the degree of procyclicality of the system because the risk level, measured by the unconditional portfolio default rate, $\bar{p}$, is treated as exogenous and fixed. In order to assess the cyclicality of capital requirements, we thus need to make the model environment dynamic and introduce a business cycle into it. To do so we let $\bar{p}$ take on two values, corresponding to expansion and recession times. Formally, we allow for two possible states of the economy: $y_{t} \in\{0,1\} . y_{t}=0$ corresponds to a recession and $y_{t}=1$ to an expansion period. The variable $y_{t}$ is assumed to follow a first-order Markov process, with the following transition probabilities matrix, based on estimates from a regime-switching model for US GDP quarterly data (for period 1959Q1-2011Q2):

$$
\left[\begin{array}{ll}
q_{00} & q_{01} \\
q_{10} & q_{11}
\end{array}\right]=\left[\begin{array}{ll}
0.38 & 0.62 \\
0.03 & 0.97
\end{array}\right]
$$

with $q_{i j}$ denoting the probability of moving from state $i$ to state $j$ during one quarter. The probability of a default, $p_{t}$, is a function of the state of the economy such that: $\bar{p}(0)=a, \bar{p}(1)=b$ and $a>b$, i.e. the mean individual probability of a firm (in the bank's portfolio) defaulting is higher during recessions. In our numerical exercise we set $\bar{p}(0)=0.03 \times 0.25=0.0075$ and $\bar{p}(1)=0.01 \times 0.25=0.0025$. We take those values from the "Commercial Banks in 1999" Special Report by the Federal Reserve Bank of Philadelphia. ${ }^{16}$

\footnotetext{
${ }^{15}$ Tier 1 consists of common equity, retained earnings and preferred stock, while Core Tier 1 consists of common equity and retained earnings only. Tier 2 includes "hybrid" debt/equity capital instruments, subordinated debt, undisclosed reserves, revaluation and general loan-loss reserves.

${ }^{16}$ We again use the rule of thumb to derive quarterly default probabilities based on annual values taken from the data. Moreover, the values of annual unconditional default probabilities are in line with Repullo and Suarez (2012), who conduct a similar analysis of pro-cyclicality of the excess capital held by banks in a simple overlapping generation model. However, they do not consider the impact of regulatory penalties. See Appendix 7C for calibration details.
} 
To compare changes to be introduced under Basel III with current Basel-II provisions, we calibrate the regulatory capital ratio, which now will be different in the two states of the economy (we use $k_{0}^{\text {reg }}$ to denote the regulatory capital ratio corresponding to recessions, and $k_{1}^{r e g}$ to denote the minimum requirement for expansion times under the regulatory regime "reg") according to the two versions of Basel Accords. First we apply the Vasicek (2002) model and calculate Basel-II provisions as corresponding to the confidence level of $\alpha=0.999$ and equal $k_{0}^{\text {Basel-II }}=5.5 \%$ and $k_{1}^{\text {Basel }_{-} I I}=2.7 \%$ in our simple setup. We then model the increase in the overall capital requirement under Basel III (the conservation buffer) as corresponding to a new, higher confidence level, $\alpha^{\text {new }}=0.9997^{17}$. Under this specification we obtain $k_{0}^{\text {conservation_buffer }}=10.65 \%$ and $k_{1}^{\text {conservation_buffer }}=5.5 \%$. Finally, under the two-risk-function Basel-III requirements (i.e. accounting for the conservation buffer AND for the countercyclical buffer) we additionally adjust the requirement in the expansion state, which gives us $k_{0}^{\text {Basel_III }}=10.65 \%$ and $k_{1}^{\text {Basel-III }}=5.5 \%+2.5 \%=8 \%$.

In the new model the bank solves one of two Bellman equations, depending on the state of the economy at the beginning of each period $\left(y_{t-1}\right)$. During the period, $t$, the new state $y_{t}$ is realized, with the transition probabilities conditional on $y_{t-1}$. In this setting the interest rate on the bank's portfolio, $r_{t}$, depends on the begining-of-period state of the economy, $y_{t-1}$, and is calculated as the average of interest rates corresponding to two different states of the economy, weighted by the conditional probabilities of each state occuring during current period. Finally, we assume that the minimum requirement binding for the bank in given period is the one corresponding to the state of the economy at the beginning of the period $\left(y_{t-1}\right)$. The exact derivations of the relevant Bellman equations are presented in Appendix 7B.

\subsubsection{The impact of the Basel-III countercyclical buffer on the overall cyclicality of the system of capital requirements}

Table 3 contains the results of this numerical exercise for three alternative specifications of capital requirements: (A) Basel II regulations, (B) increased total capital requirement under Basel III but without the countercyclical buffer, and (C) case (B) plus the countercyclical buffer; Case C thus represents Basel III completely as far is its impact on overall capital requirements is concerned. We used equation (12) to model the ex-post penalty, i.e. we included the reputational aspects of requirements violation and not the lighter variant.

After deriving actual capital choices in the two states of nature numerically, a simple simulation exercise was performed. The variable $p_{t}$ was drawn one million times for each of the above cases. For each draw, given the regulatory minimum requirement and bank's actual capital, the end-of-period common equity $\left(k_{t}^{\prime}\right)$ was calculated. Table 3 reports the average value of $k_{t}^{\prime}$ as well as the total number of defaults and the number of capital requirements violations based on all simulations. Note that each of the simulated observations was treated as independent, i.e. a single period of the bank's life was simulated one million times.

Conservation buffer Consider the changes in actual capital fluctuations resulting from the introduction of the conservation buffer under Basel III, which corresponds to moving from case (A) to case (B). First,

\footnotetext{
${ }^{17}$ We derive $\alpha^{\text {new }}$ as corresponding to a new higher minimum requirement of $8.4 \%$ under Vasicek (2002) model and assuming $\bar{p}=0.02$.
} 
it turns out that the variation of actual capital along the cycle decreases only slightly after introduction of the conservation buffer, which means it will have little effect on reducing the procyclicality of the system. Most importantly however, the size of the decrease in actual capital variation is considerably smaller once the ex-post violation penalties are accounted for: under no penalty model specification the capital variability falls by $10 \%$ (from $103.7 \%$ to $93.4 \%$ ), while introducing the violation penalty to the model gives a fall of $3.5 \%$ (from $90.2 \%$ to $87 \%)^{18}$. This happens as excess capital in presence of ex-post violation penalties does not decrease with increasing required confidence level, while the marginal increase in minimum capital requirements is always falling with $\alpha$.

Countercyclical buffer Finally, Table 3 shows that the countercyclical buffer under Basel III significantly reduces fluctuations of actual capital along the cycle for both model specifications. The relative change in actual capital between expansion and recession falls from from $87 \%$ to $37.2 \%$ when incorporating the violation penalty (and from $93.4 \%$ to $33.1 \%$ in the absence of violation penalties). While the fall is obviously (relatively) smaller in the latter case, it is still considerable. Clearly, the countercyclical buffer is not high enough to eliminate actual capital fluctuations entirely, but it is smoothes them significantly. This is one of the key results of our analysis, as - to our knowledge - so far no one has attempted to evaluate the impact of the countercyclical buffer on actual capital fluctuations. The numbers show that even a buffer as small as $2.5 \%$ reduces the pro-cyclicality considerably. ${ }^{19}$

\begin{tabular}{|c|c|c|c|}
\hline & Case (A) & Case (B) & Case (C) \\
\hline \hline$k_{0}^{\text {reg }} / k_{1}^{\text {reg }}$ & $5.5 / 2.7$ & $10.65 / 5.5$ & $10.65 / 8$ \\
\hline Actual capital $k_{0}^{a c t} / k_{1}^{a c t}$ & $7.8 / 4.1$ & $12.9 / 6.9$ & $12.9 / 9.4$ \\
\hline Capital buffers (in level) & $2.3 / 1.4$ & $2.25 / 1.4$ & $2.25 / 1.4$ \\
\hline Relative Difference $\frac{k_{0}^{\text {act }}-k_{1}^{a c t}}{k_{1}^{a c t}}$ in $\%$ & $90.2 \%$ & $87 \%$ & $37.2 \%$ \\
\hline Subordinate debt & $3 / 3.96$ & $3 / 3$ & $3 / 3$ \\
\hline Deposits & $89.2 / 91.9$ & $84.1 / 90.1$ & $84.1 / 87.6$ \\
\hline Number of defaults & 0 & 0 & 0 \\
\hline Violations per 1000 obs. & 2.18 & 2.16 & 2.16 \\
\hline Mean end-of-period capital & 4.53 & 7.44 & 9.84 \\
\hline Economic capital level & \multicolumn{3}{|c|}{$0.5 / 0.5$} \\
\hline Economic sub. debt level & \multicolumn{3}{|c}{$95.5 / 95.5$} \\
\hline Economic deposits level & \multicolumn{3}{|c}{} \\
\hline
\end{tabular}

Table 3: Regulatory penalties and the countercyclical buffer. Values of common equity, subordinate debt, deposits and retained earnings reported as \% of assets.

Our simulation exercises also show that when ex-post penalties are not incorporated to the model, the bank does not comply with regulatory requirements every 7 out of 100 quarters, but once they are in place, banks are only out of compliance in 2 out of 1000 quarters, a decline by a factor 35, bringing this measure more in line with observed frequencies.

\footnotetext{
${ }^{18}$ See Table 5 in the Appendix for the results of the numerical exercise for a specification without ex-post violation penalty.

${ }^{19}$ A separate issue is the feasibility of the countercyclical buffer in presence of "reputational" costs of minimum requirement violation, as mentioned in WSBI (2010) and quoted in Section 3.2.2.
} 


\subsection{Tier 2 capital and the "bail-in" proposal}

Basel-III provisions also lower the fraction of the regulatory minimum capital requirement that can be met in the form of Tier-2 capital: this is mainly because of rising concerns over the macroprudential role of hybrid instruments like subordinate loans (see Section 1). Meanwhile, on the 6th June 2012 the European Commission revealed the "Bank Recovery and Resolution Proposal" ${ }^{20}$ : a set of proposals aimed at limiting public help in case of a bank's insolvency. One of proposed solutions is a so-called "bail-in" procedure, where a failing institution would be forced to write down and/or convert to equity some of its liabilities before asking for public help in case of a distress. "Bail-in" would potentially apply to any liabilities not backed by assets or collateral, such as subordinate debt and senior liabilities. More importantly, to assure that banks hold a sufficient amount of liabilities subject to a possible write-down, they would be required to hold at least $10 \%$ of total liabilities in these special types of capital. This proposal of the European Commission, announced not more than 2 years after the presentation of the new framework of Basel III, in practice boils down to introducing a new (and a much higher) Tier-2 capital requirement. It also shows that regulators still have problems with unambiguous evaluation of the macroprudential properties of subordinate debt and similar hybrid instruments.

We contribute to the discussion over the role of Tier-2 capital by investigating the "bail-in" proposal within our theoretical setting from Section 2: the subordinate debt introduced there as a funding source can be interpreted as Tier-2 capital. Subordinate debt plays a double role in our framework: it increases the moral hazard friction, but at the same time it is a potential market-disciplining tool via the interest rate $r_{t}^{e}$ since the latter increases in the default risk (thus, we can investigate the direct market-disciplining role of Tier-2 capital, i.e. via the impact of the risk-sensitive interest rate on funding costs for the bank). In this setting raising minimum capital requirements, by increasing actual capital ratios, should lower the uncertainty over payoffs to subordinate debt owners and hence lower the interest rate they willvdemand for given levels of subordinate debt. In the analysis that follows we want to verify by how much the risk-sensitivity of the subordinate-debt interest rate would decrease after introduction of the European Commission's plans.

We start by plotting the subordinate debt interest rate, $r_{t}^{e}$, corresponding to different levels of portfolio risk, $\bar{p}$, for the Basel-II minimum level of subordinate debt, $\bar{e}=0.04$, in Figure 5 (upper panel). The plot shows that the interest rate responds the most to increasing portfolio risk when no ex-post violation penalties are present. Introducing such regulatory penalties significantly reduces - because of increased actual capital ratios - the responsiveness of $r_{t}^{e}$ to the level of risk. In fact, the line representing $r_{t}^{e}$ is almost entirely flat when "reputational" costs of non-compliance are also accounted for. We conclude that the higher level of common equity, the smaller the market disciplining role of subordinate debt. Thus the two proposals (BaselIII and the EU proposal on bail-in capital) seem to some extent to work at cross purposes. If we are right, if the suggested changes in Tier-1 capital requirements under Basel III would lead - as our analysis shows - to significant increases in actual capital ratios and a much reduced market disciplining effect of Tier-2 capital, then requiring these high bail-out ratio's is probably unnecessary and ineffective, as many studies suggest (Turner (2009)).

\footnotetext{
${ }^{20}$ Source: http://europa.eu/rapid/pressReleasesAction.do? reference $=M E M O / 12 / 416 \mathfrak{6}$.
} 

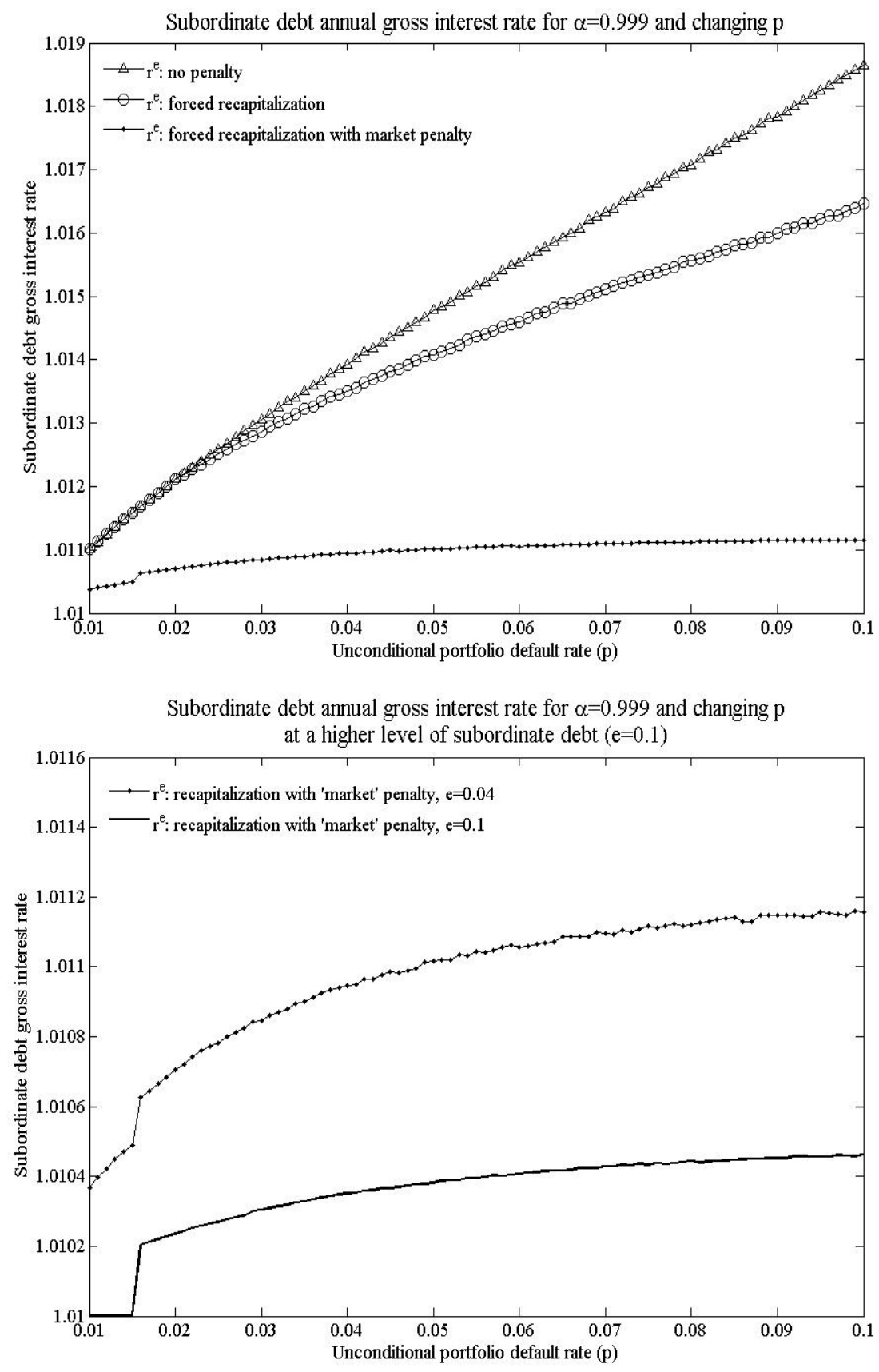

Figure 5: Subordinate debt interest rate $\left(r_{t}^{e}\right)$ for changing $\bar{p} \alpha=0.999$.

In the second part of our exercise we consider the change from the Basel-II minimum level of subordinate debt $(\bar{e} \simeq 0.04)$ to a new higher level compatible with the European Commission's proposal for "bail-in" debt, i.e. $\bar{e}^{\text {new }} \simeq 0.1$. We then compare actual capital ratio's before and after this change for four different 
levels of the risk level in the economy ( $\bar{p}=\{0.01,0.02,0.03,0.04\})$ in Table 4 below.

As one might expect, when the steady state ratio, $\bar{e}$, is increased, subordinate debt substitutes for common equity in the absence of capital regulations preventing that: the economic capital ratio is now the lowest one allowed by the grid for all considered levels of risk, $\bar{p}$. On the contrary, introducing minimum capital requirements motivates banks to hold actual capital ratios well above the economic capital ratio, just like what comes out for the old, lower level of $\bar{e}$. This suggests a justification for introducing higher capital requirements into the banking sector to prevent a detererioration of the quality of capital once the strong "bail-in" requirements are introduced. It also shows that in presence of capital requirements the share of subordinate debt following the "bail-in" proposal will be increased at the expense of the deposits share in a bank's total liabilities. In the presence of ex-post violation penalties banks will be unwilling also to reduce their capital buffers (held in excess of the regulatory minimum) to compensate for the increased subordinate debt level so it has to come from somewhere else.

\begin{tabular}{|c|c|c|c|c|c|c|c|c|}
\hline \multicolumn{2}{|c|}{ Case } & $\bar{p}=0.01$ & $\bar{p}=0.02$ & $\bar{p}=0.04$ & $\bar{p}=0.06$ & $\bar{p}=0.08$ & $\bar{p}=0.1$ \\
\hline \hline \multirow{3}{*}{$\bar{e} \simeq 0.04$} & \multicolumn{2}{|c|}{ economic capital } & 0.5 & 0.5 & 0.79 & 2.03 & 3.13 & 4.18 \\
\cline { 2 - 9 } & \multirow{2}{*}{ actual capital } & no penalty & 2.71 & 4.28 & 6.61 & 8.35 & 9.78 & 10.97 \\
\cline { 2 - 9 } & & penalty & 3.98 & 6.43 & 10.07 & 12.91 & 15.26 & 17.29 \\
\hline \hline \multirow{3}{*}{$\bar{e} \simeq 0.1$} & \multicolumn{2}{|c|}{ economic capital } & 0.5 & 0.5 & 0.5 & 0.5 & 0.5 & 0.5 \\
\cline { 2 - 9 } & \multirow{2}{*}{ actual capital } & no penalty & 2.71 & 4.28 & 6.61 & 8.35 & 9.78 & 10.97 \\
\cline { 2 - 9 } & & penalty & 3.98 & 6.43 & 10.07 & 12.91 & 15.26 & 17.29 \\
\hline
\end{tabular}

Table 4: Increasing steady state subordinate debt level: impact on actual capital (reported as \% of assets).

Finally, the bottom panel of the Figure 5 compares the subordinate debt interest rates realized under the baseline and under the new subordinate debt level, for varying $\bar{p}$. The new interest rate $r_{t}^{e}$ almost does not respond to increasing portfolio risk at all: the line representing subordinate debt interest rates corresponding to different levels of $\bar{p}$ is almost entirely flat. As higher amount of subordinate debt held implies lower level of deposits (with actual capital falling only slightly and hence remaining on a relatively high level), the probability of a bank's default decreases further, lowering the premium demanded by subordinate debt holders. Of course, increasing the share of subordinate debt in banks' liabilities lowers the probability of a default and hence the need of a government's intervention (as now losses will be borne to a higher extent by capital owners). However, the above exercise shows that a too high level of subordinate-debt-types capital (i.e. subject to a write-down) reduces their market disciplining role further.

\section{Conclusions and possible extensions}

So far, the standard way of modeling capital requirements in the literature has been to assume that they affect banks' actual capital choices only when they bind, i.e. that a bank opts for an amount of own capital higher than the regulatory minimum only if the latter is anyway lower than the economic capital preferred by the bank in absence of any regulations. Otherwise the bank always chooses to hold actual capital equal to the minimum required, which implies zero capital buffers. But it is a strong stylized fact that banks hold 
own capital in excess of the regulatory minimum. In this study we explain the abovementioned empirical evidence by pointing at existence and implications of ex-post regulatory and "market" penalties for not meeting capital requirements. In the presence of such anticipated penalties, banks choose actual capital higher than the regulatory requirement for all levels of portfolio risk considered. Importantly, we also show that adjustments in those capital buffers to changes in capital requirements can have a substantial impact on the evaluation of regulatory frameworks: the same policies can in fact lead to different outcomes (in terms of achieved actual capital ratios, the procyclicality of the system, etc.) once such behavioral responses of banks are correctly accounted for. Key conclusions of our analysis can be outlined as follows:

Positive excess capital. Introducing regulatory penalties for not meeting capital requirements results in actual capital choices above the regulatory minima, which could not be explained by the model without such penalties. The strongest impact of the penalty on the actual capital held (i.e. highest levels of the latter) is obtained in case of the penalty cost specification (12). Under this specification, simulated buffers are in the range observed in practice. Using this penalty form can be interpreted as imposing additional "market" penalty on the bank. Also, average levels of actual capital derived in this setting are in line with empirical evidence.

Excess capital increasing with the level of risk. Actual capital goes up more than regulatory capital as the riskiness of the portfolio increases under all specifications of the out-of-compliance penalty. In other words, excess capital is positively correlated with the level of risk in the economy. Therefore, single-riskcurve capital regulation, such as Basel II, is even more pro-cyclical (in terms of exacerbating business cycle fluctuations) than one would expect from the procyclicality of the requirements only.

Significant impact of the countercyclical buffer. A simple exercise comparing Basel-II and Basel-III capital regulations shows that because of the positive correlation between excess capital and the level of risk in the economy in the presence of ex-post violation penalties, raising the overall level of capital requirements does not reduce the pro-cyclical character of capital requirements. But we show that introduction of a countercyclical buffer, aimed at resembling a two-risk-curve capital requirements schedule and provisioned under Basel III, is highly desirable because it significantly reduces procyclical fluctuations in actual capital. To our knowledge - so far no one has attempted to evaluate the quantitative impact of the countercyclical Basel-III buffer on actual capital fluctuations. Our results suggest that the impact of even the limited 2.5\% buffer envisaged will be considerable.

Market-disciplining role of Tier-2 capital negatively affected by the level of common equity. The Tier-2-types of capital, such as subordinate debt, are supposed to serve as a market disciplining tool, limiting the risk taken by banks. However, in presence of capital requirements and ex-post violation penalties the actual capital levels are much higher and the interest rate on subordinate debt is much less sensitive to changes in the level of risk than in absence of such regulations. Thus, capital minima, together with ex-post regulatory and "market" penalties for not meeting them, can actually negatively affect the adequacy of Tier-2 capital for macroprudential goals. 
Capital requirements to be set below the socially optimal capital level to achieve the latter. Although derivation of the socially optimal capital level is beyond the scope of this paper, the presence of ex-post non-compliance penalties has implications that are worth stressing. That is, if social welfare is maximized at a certain level of capital ratios, the regulator should set capital requirements below that socially optimal capital level, as in general the actual capital held by the banks will exceed the regulatory minimum once the "market" and regulatory penalties are accounted for. This conclusion is especially important in presence of "market" penalties which are beyond control of regulatory authorities.

Our model is admittedly a very simplified description of regulatory practices and the capital choices banks make. Nevertheless, we obtain results that are in line with empirical evidence and seem to have substantial policy relevance. A desirable extension of our model would be to endogenize the portfolio risk decision. In the future we also plan to investigate the channels through which banks adjust to capital requirements more in detail: distinguishing between "cosmetic changes" like reduction in total asset size with simultaneous increase in the portfolio risk versus more "structural changes" like increasing the capital base and reducing risk exposure. Another extension of the analysis presented here would involve distinguishing between different regulatory policies available to regulators in case of requirements violation and investigation of their macroeconomic implications. 


\section{References}

1. Acharya, V., Mehran, H., Schuermann T. and A. Thakor (2011), Robust Capital Regulation, Federal Reserve Bank of New York Staff Report no. 490.

2. Adrian T. and H. Shin (2010), Liquidity and Leverage, Journal of Financial Intermediation vol. 19, pp. 418-437.

3. Agur, I. (2010), Capital Requirements and Credit Rationing, DNB Working Paper 257/2010.

4. Altman, E., Brady, B., Resti, A. and A. Sironi (2005), The Link between Default and Recovery Rates: Theory, Empirical Evidence, and Implications, Journal of Business vol. 78, pp. 2203-2227.

5. Ayuso, J., Perez, D. and J. Saurina (2004), Are Capital Buffers Pro-Cyclical? Evidence from Spanish Panel Data, Journal of Financial Intermediation, vol. 13(2), pp. 249-264.

6. Basel Committee (2010), Basel III, a Global Regulatory Framework for More Resilient Banks and Banking Systems, Bank For International Settlements, Basel.

7. Basel Committee (2006), International Convergence of Capital Measurement and Capital Standards, Bank For International Settlements, Basel.

8. Barrell, R., E. P. Davis, T. Fic and D. Karim (2011), Bank Capital Composition, Regulation and Risk Taking, forthcoming.

9. Bec, F. and Ch. Gollier (2009), Cyclicality and Term Structure of Value-at-Risk in Europe, Institut d'Économie Industrielle (IDEI) Working Papers 587.

10. Benes, J. and M. Kumhof (2011), Risky Bank Lending and Optimal Capital Adequacy Regulation, IMF Working Paper 11/130.

11. Blum, J. and M. Hellwig (1995), The Macroeconomic Implications of Capital Requirements for Banks, European Economic Review vol. 39, pp. 739-749.

12. Cournède, B. and P. Slovik (2011), Macroeconomic Impact of Basel III, OECD Economics Department Working Paper 844.

13. Diamond, D. and R. Rajan (2009), Fear of Fire Sales and the Credit Freeze, NBER Working Papers 14925 .

14. Elizalde, A. and R. Repullo (2007), Economic and Regulatory Capital in Banking: What Is the Difference?, International Journal of Central Banking vol. 3(3), pp. 87-117.

15. Estrella, A. (2004), The Cyclical Behavior of Optimal Bank Capital, Journal of Banking and Finance vol. 28 , pp. 1469-1498.

16. Estt, B. (1997), Organizational Form and Risk Taking in the Savings and Loan Industry, Journal of Financial Economics vol. 44, pp. 25-55. 
17. Francis, W. and M. Osborne (2009b), Regulation, Capital and Credit Supply in the UK Banking Industry: Measuring the Impact of Prudential Standards, Financial Services Authority Occasional Paper no. 36 .

18. Furfine, C. (2001), Bank Portfolio Allocation: The Impact of Capital Requirements, Regulatory Monitoring, and Economic Conditions, Journal of Financial Services Research vol. 20(1), pp. 33-56.

19. Galati, G. and R. Moessner (2011), Macroprudential Policy - a Literature Review, BIS Working Papers 337.

20. Gerali, A., Neri, S., Sessa, L. and F. Signoretti (2010), Credit and Banking in a DSGE Model of the Euro Area, Bank of Italy Working Paper Series, No. 740.

21. Gertler, M. and P. Karadi (2011), A Model of Unconventional Monetary Policy, Journal of Monetary Economics vol. 58(1), pp. 17-34.

22. Gertler, M., N. Kiyotaki and A. Queralto (2011), Financial Crises, Bank Risk Exposure and Government Financial Policy, forthcoming.

23. Gordy, M. (2003), A Risk-Factor Model Foundation for Ratings-Based Bank Capital Rules, Journal of Financial Intermediation vol. 12(3), pp. 199-232.

24. Gorton, G. and R. Rosen (1995), Corporate Control, Portfolio Choice, and the Decline of Banking, Journal of Finance vol. 50(5), pp. 1377-1400.

25. Heid, F. (2007), The Cyclical Effects of the Basel II Capital Requirements, Journal of Banking and Finance vol. 31, pp. 3885-3900.

26. Huang, J. and M. Huang (2003), How Much of the Corporate-Treasury Yield Spread is Due to Credit Risk?, Unpublished.

27. Jokipii, T. and A. Milne (2008), The Cyclical Behaviour of European Bank Capital Buffers, Journal of Banking and Finance vol. 32(8), pp.1440-1451.

28. Kashyap, A. and J. Stein (2004), Cyclical Implications of the Basel-II Capital Standards, Journal of Economic Perspectives, Federal Reserve Chicago, vol. 1, pp. 18-31.

29. King, M. (2009), The Cost of Equity for Global Banks: a CAPM Perspective from 1990 to 2009, BIS Quarterly Review, Bank for International Settlements, September, pp. 59-73.

30. Krishnan, C., Ritchken, P. and J. Thomson (2005), Monitoring and Controlling Bank Risk - Does Risky Debt Help?, Journal of Finance vol. 60, pp. 343-378.

31. Lindquist, K-G. (2004), Banks' buffer capital: how important is risk?, Journal of International Money and Finance vol. 23, pp. 493-513. 
32. Lucas, R., Stokey, N. and E. Prescott (1989), Recursive Methods in Economic Dynamics, Harvard University Press, Chapter 3.

33. Maccario A., Sironi, A. and C. Zazzara (2002), Is Banks' Cost of Equity Capital Different Across Countries? Evidence from the G10 Countries Major Banks, SDA Bocconi Research Division Working Paper 02-77.

34. Milne, A. and E. Whalley (2001), Bank Capital Regulation and Incentives for Risk-Taking, Cass Business School Research Paper.

35. Milne, A. (2002), Bank Capital Regulation as an Incentive Mechanism: Implications for Portfolio Choice, Journal of Banking and Finance vol. 26(1), pp. 1-23.

36. Morgan, D. and K. Stiroh (2005), Too Big to Fail After All These Years, Federal Reserve Bank of New York, Staff Reports 220.

37. Myers, S. and N. Majluf (1984), Corporate Financing and Investment Decisions When Firms Have Information that Investors Do Not Have, Journal of Financial Economics vol. 13(2), pp. 187-221.

38. Repullo, R. and J. Suarez (2012), The Procyclical Effects of Bank Capital Regulation, CEPR Discussion Papers 8897.

39. Roger, S. and F. Vitek (2012), The Global Macroeconomic Costs of Raising Bank Capital Adequacy Requirements, IMF Working Paper 12/44.

40. Salas, V. and J. Saurina (2002b), Credit Risk in Two Institutional Regimes: Spanish Commercial and Savings Banks, Deutsch Journal of Financial Services Research vol. 22 (3), pp. 203-224.

41. Stolz, S. and M. Wedow (2005), Banks' regulatory capital buffer and the business cycle: evidence for German savings and cooperative banks, Discussion paper Series 2: Banking and Financial Studies 2005, Deutsche Bank, Research Centre.

42. Sironi, A. (2001), An Analysis of European Banks SND Issues and Its Implications for the Design of a Mandatody Subordinated Debt Policy, Journal of Financial Services Research vol. 20(2), pp. 233-266.

43. Turner, A. (2009), A Regulatory Response to the Global Banking Crisis (The Turner Review), FSA, London.

44. Van den Heuvel, S.J. (2008), The Welfare Cost of Bank Capital Requirements, Journal of Monetary Economics vol. 55, pp. 298-320.

45. Vasicek, O. (2002), Loan Portfolio Value, Risk, pp. 160-162.

46. Wall, L. and P. Peterson (1996), Banks' Responses to Binding Regulatory Capital Requirements, Economic Review, Federal Reserve Bank of Atlanta, vol. 81 (2), pp. 1-17.

47. World Savings Banks Institute (2010), WSBI-ESBG Position Regarding the Basel Consultation on a "Countercyclical Capital Buffer Proposal" (BCBS 172), WSBI-ESBG Document 0992/2010. 


\section{Appendices}

\section{A: Single Risk Factor Model}

The cumulative distribution function is given by:

$$
F\left(p_{t}\right)=\Phi\left(\frac{\sqrt{1-\rho} \Phi^{-1}\left(p_{t}\right)-\Phi^{-1}(\bar{p})}{\sqrt{\rho}}\right)
$$

and the corresponding density function is following:

$$
f\left(p_{t}\right)=\sqrt{\frac{1-\rho}{\rho}} \exp \left\{-\frac{1}{2 \rho}\left(\sqrt{1-\rho} \Phi^{-1}\left(p_{t}\right)-\Phi^{-1}(\bar{p})\right)^{2}+\frac{1}{2}\left(\Phi^{-1}\left(p_{t}\right)\right)^{2}\right\}
$$

where, accroding to Basel-II provisions for corporate, sovereign and bank exposures, the correlation coefficient $\rho$ is a function of $\bar{p}$ :

$$
\rho(\bar{p})=0.24-0.12 \frac{1-e^{50 \bar{p}}}{1-e^{50}}
$$

The above formulas follow from Vasicek (2002) as the limit solution for a portfolio loss rate distribution with the size of portfolio: $N \rightarrow \infty$. $\Phi$ denotes the cumulative standard normal distribution. We deviate from the Vasicek model by assuming that the correlation coefficient, $\rho$, is independent of $\bar{p}$ and fixed (see Part $\mathrm{C}$ of the Appendix for justification).

\section{B: Value Function Iteration Algorithm}

\section{Analytical expressions}

Using the fact that $F\left(p_{t}\right)$ is the cdf of $p_{t}$, the Bellman equation (8) can be simplified to:

$$
V_{t}=\max _{k_{t}, e_{t} \in[0,1]}\left[-k_{t}+\frac{1}{r^{k}}\left(\left(r-r^{d} d_{t}-r_{t}^{e} e_{t}\right) F\left(\hat{p}_{t}\right)-(r-\lambda) \int_{0}^{\hat{p}_{t}} p_{t} f\left(p_{t}\right) d p_{t}\right)+F\left(\tilde{p}_{t}\right) V_{t+1}\right]
$$

where $\hat{p}_{t}=\frac{r-r^{d} d_{t}-r_{t}^{e} e_{t}}{r-\lambda}$ and $\tilde{p}_{t}=\frac{r-r^{d} d_{t}}{r-\lambda}$.

The subordinate debt interest rate equation (5) simplifies to:

$$
r^{d} e_{t}=\left[r_{t}^{e} e_{t} F\left(\hat{p}_{t}\right)+\left(\left(r-r^{d} d_{t}\right)\left(F\left(\tilde{p}_{t}\right)-F\left(\hat{p}_{t}\right)\right)-(r-\lambda) \int_{\hat{p}_{t}}^{\tilde{p}_{t}} p_{t} f\left(p_{t}\right) d p_{t}\right]\right.
$$

Case with the violation penalty: forced recapitalization If the additional penalty for not meeting capital requirements is introduced to the model, the Bellman equation (10) extends to:

$$
V_{t}=\max _{k_{t}, e_{t} \in[0,1]}\left[-k_{t}+\frac{1}{r^{k}}\left(\left(r-r^{d} d_{t}-r_{t}^{e} e_{t}\right) F\left(\hat{p}_{t}\right)-(r-\lambda) \int_{0}^{\hat{p}_{t}} p_{t} f\left(p_{t}\right) d p_{t}+F\left(\tilde{p}_{t}\right) V_{t+1}-\right.\right.
$$




$$
\left.\left.\frac{1}{r^{k}}\left(r^{k}-r^{d}\right)\left[k^{r e g}\left(F\left(\tilde{p}_{t}\right)-F\left(p_{t}^{*}\right)\right)-\left(r-r^{d} d_{t}-r_{t}^{e} e_{t}\right)\left(F\left(\hat{p}_{t}\right)-F\left(p_{t}^{*}\right)\right)+(r-\lambda) \int_{p_{t}^{*}}^{\hat{p}_{t}} p_{t} f\left(p_{t}\right) d p_{t}\right]\right)\right]
$$

subject to the incentive constraint (6), the balance sheet clearing condition, the capital constraint (9), and where $p_{t}^{*}=\frac{r-r^{d} d_{t}-r_{t}^{e} e_{t}-k^{r e g}}{r-\lambda}$.

The Bellman equation for the alternative penalty specification (12) can be derived in an analogous way.

Two-state economy case After distinguishing between recession and expansion times, the Bellman equation (10) for state $y_{i}, i \in\{0,1\}$ changes accordingly to:

$$
\begin{aligned}
V_{t}= & \max _{k_{t}, e_{t} \in[0,1]}\left[-k_{t}+\frac{1}{r^{k}}\left(\left(r-r^{d} d_{t}-r_{t}^{e} e_{t}\right) \check{F}_{i}\left(\hat{p}_{t}\right)-(r-\lambda) \sum_{j=0,1} q_{i j} \int_{0}^{\hat{p}_{t}} p_{t} f_{j}\left(p_{t}\right) d p_{t}+\check{F}_{i}\left(\tilde{p}_{t}\right) V_{t+1}-\frac{1}{r^{k}}\left(r^{k}-r^{d}\right) \times\right.\right. \\
& {\left.\left.\left[k^{r e g}\left(\check{F}_{i}\left(\tilde{p}_{t}\right)-\check{F}_{i}\left(p_{t}^{*}\right)\right)-\left(r-r^{d} d_{t}-r_{t}^{e} e_{t}\right)\left(\check{F}_{i}\left(\hat{p}_{t}\right)-\check{F}_{i}\left(p_{t}^{*}\right)\right)+(r-\lambda) \sum_{j=0,1} q_{i j} \int_{p_{t}^{*}}^{\hat{p}_{t}} p_{t} f_{j}\left(p_{t}\right) d p_{t}\right]\right)\right] }
\end{aligned}
$$

where $\check{F}_{i}\left(p_{t}\right)=\sum_{j=0,1} q_{i j} F\left(\bar{p}_{j}\right), f_{j}\left(p_{t}\right)=\sqrt{\frac{1-\rho}{\rho}} \exp \left\{-\frac{1}{2 \rho}\left(\sqrt{1-\rho} \Phi^{-1}\left(p_{t}\right)-\Phi^{-1}\left(\bar{p}_{j}\right)\right)^{2}+\frac{1}{2}\left(\Phi^{-1}\left(p_{t}\right)\right)^{2}\right\}$ and where the interest rate $r_{t}^{e}$ was solved for from the equation:

$$
r^{d} e_{t}=\left[r_{t}^{e} e_{t} \check{F}\left(\hat{p}_{t}\right)+\left(r-r^{d} d_{t}\right)\left(\check{F}\left(\tilde{p}_{t}\right)-\check{F}\left(\hat{p}_{t}\right)\right)-(r-\lambda) \sum_{j=0,1} q_{i j} \int_{\hat{p}}^{\tilde{p}_{t}} p_{t} f_{j}\left(p_{t}\right) d p_{t}\right]
$$

The thresholds $p_{t}^{*}, \tilde{p}_{t}$ and $\hat{p}_{t}$ were set using the subordinate interest rates solved for from the above equation.

\section{Grid}

The VFI algorithm was performed on a discrete grid of capital $G_{k}=\left\{k_{1}, k_{2}, \ldots k_{N}\right\}$ and subordinate debt $G_{e}=\left\{e_{1}, e_{2}, \ldots e_{M}\right\}$ pairs (the values of deposit fraction, $d_{i j}$ follow automatically from: $d_{i j}=1-k_{i}-e_{i j}$ ) with $N=1000$ and $M=100$, i.e. for each $k_{i} 100$ alternative values of $e_{i j}$ spread across the interval [0.03, 0.15] were available. The imposed range for capital was the interval $[0.005,0.2]$. As the policy and value functions were expected to be highly nonlinear for low values of capital, non equidistant grid for capital with higher density of points in the lower range of capital values was used to increase the accuracy of the fit. The grid was constructed according to the rule $k_{i}=k_{1}+\delta(i-1)^{2}, i=1,2, \ldots N$ with $\delta=\left(k_{N}-k_{1}\right) /(N-1)^{2}$. The same algorithm was used for construction of the subordinate debt grid.

Given the grid pair $\left\{k_{s}, e_{s}\right\}$, the corresponding interest rates $r_{s}^{e}$ were numerically approximated. In particular, the Gauss-Chebyshev quadrature on 100 Chebyshev nodes was used to approximate the integral $\int_{\hat{p}}^{\tilde{p}_{t}} p_{t} f\left(p_{t}\right) d p_{t}$ in the equation for the subordinate interest rate $(5)$. 


\section{Iterative algorithm}

The Value Function Iteration algorithm was performed on the grid of total size $I=N \times M=100000$. As each period the optimal capital and subordinate debt levels were chosen as fractions of total liabilities, there was no state variable in this simple optimization problem. Therefore, the optimal solution in each of the grid points was independent of the the value of capital, subordinate debt and interest rates in this grid point. In particular, in each iteration step, $m$, the following procedure was implemented (for the baseline Bellman equation (8) subject to the incentive constraint (6), the balance sheet clearing condition, and the capital requirement $(9))$ :

1. For each grid point $i=1, \ldots, I$ compute

$$
\begin{aligned}
V_{i}^{m}=-k_{i}+\frac{1}{r^{k}}(E[\max \{ & {\left.\left.\left[\left(1-p_{t}\right) r+p_{t} \lambda\right]-r^{d} d_{i}-\min \left\{\left[\left(1-p_{t}\right) r+p_{t} \lambda\right]-r^{d} d_{i}, r_{i}^{e} e_{i}\right\}, 0\right\}\right] } \\
+ & \left.P\left(\left[\left(1-p_{t}\right) r+p_{t} \lambda\right]>r^{d} d_{i}\right) V^{m-1}\right)
\end{aligned}
$$

2. Find the index $i^{*}$ such that $V_{i^{*}}^{m} \geq V_{i}^{m}$ among $i$ 's for which $V_{i}^{m} \geq \theta\left(e_{i}\right)$ and $k_{i} \geq k^{r e g}$ for all $i=1, \ldots I$

3. Set $V^{m}=V_{i^{*}}^{m}, k_{m}^{*}=k_{i^{*}}$

4. Compare the $V^{m}$ with $V^{m-1}$ : continue the iteration until the absolute difference is lower than a given termination condition.

The stationary point function value was used as the initial value (for $m=0$ ) of $V_{i}^{0}$ for each grid point $i$ and the termination condition was set to $1 E-25$.

\section{C: Calibration choices}

The annual intermediation margin is set to 0.01 in the baseline model. This value in line with e.g. Elizalde and Repullo (2007) or Repullo and Suarez (2012), which we want to compare our model with. The later work uses the net interest margin of $3.42 \%$ (the difference between the total interest income and the total interest expense) for US commercial banks in years 2004-2007 (FDIC Statistics on Banking ${ }^{21}$ ) extended by the service charges on deposit accounts rate of $0.55 \%$, which yields the estimate of the intermediation margin of around $4 \%$. However, at the same time the reported total non-interest expenses among US commercial banks achieve a similar level, leaving the effective loan spread above the risk-free deposit interest rate of zero percent. Setting $\delta=0.01$ seems a reasonable consesus between the estimates of the intermediation margin and the non-interest costs of banks' activity.

We set the recovery rate, $\lambda=0.55$, to match the Loss Given Default (LGD) rate under Basel-II provisions (equal to 0.45) for unsecured corporate exposures. While we are aware of the probable positive correlation between LGDs and the portfolio default rates (Altman et al. (2005)), for simplicity of exposition we keep $\lambda$ constant and in particular independent from the level of risk in the economy, as measured by $\bar{p}$. When calculating the minimum capital requirements we slightly depart from the Vasicek (2002) single risk factor

\footnotetext{
${ }^{21}$ Source: http://www2.fdic.gov/SDI/SOB/
} 
model underlying Basel regulatory provisions by assuming that the correlation coefficient, $\rho$, is independent of the unconditional default probability, $\bar{p}$. Under Basel II framework the correlation of defaults is a decreasing function of $\bar{p}$ in order to reflect the fact that smaller companies (in the bank's portfolio) are perceived as more risky but at the same time subject more to idiosyncratic shocks (and hence the common risk factors are less important for this group of firms) than their larger counterparts. As we restrain from the choice of portfolio risk and keep the unconditional default probability equal for all firms in the bank's portfolio, we decide to set $\rho$ fixed at 0.164 . It is the value corresponding to the reference level of the unconditional portfolio default rate under Basel II, i.e. $\bar{p}=0.02$.

When analyzing changes of actual capital with respect to minimum capital requirements, we consider values of $\bar{p}$ in range between 0.01 and 0.1 on annual basis. This range seems to cover average default rates characteristic for developed countries (range $[0.01,0.04]$ ) as well as to capture higher default probabilities observed in emerging markets. We use the "Commercial Banks in 1999" Special Report by the Federal Reserve Bank of Philadelphia ${ }^{22}$, in which the average shares of non-performing loans in total loans of American commercial banks are reported for different years along a full business cycle, to set the unconditional probabilities of a default during the expansion $p_{1}=0.01$ and the recession times $p_{0}=0.03$ in the alternative version of the model in Section 4.3. Therefore, the results of our simple analysis of Basel III proposals hold for advanced economies only.

\footnotetext{
${ }^{22}$ Source: http://www.philadelphiafed.org/research-and-data/publications/banking-brief/1999/bbspecial.pdf
} 


\section{D: Results}

Economic, actual and regulatory capital for $\alpha=0.999, p=0.02$ and changing $\lambda$
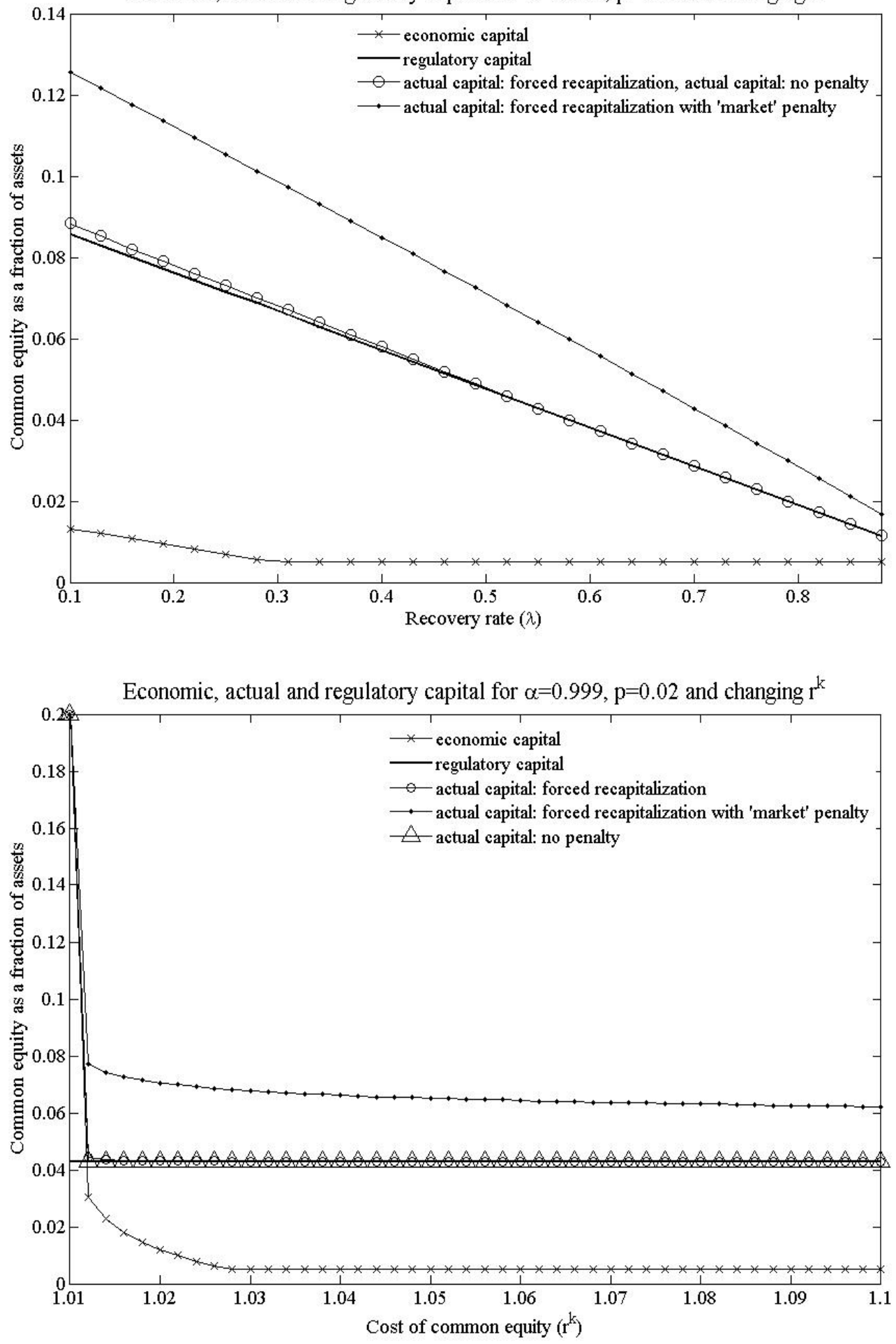

Figure 6: Changes in actual, economic and regulatory 38 capital with respect to $\lambda$ and $r^{k}, \alpha=0.999$ and $\bar{p}=0.02$. 


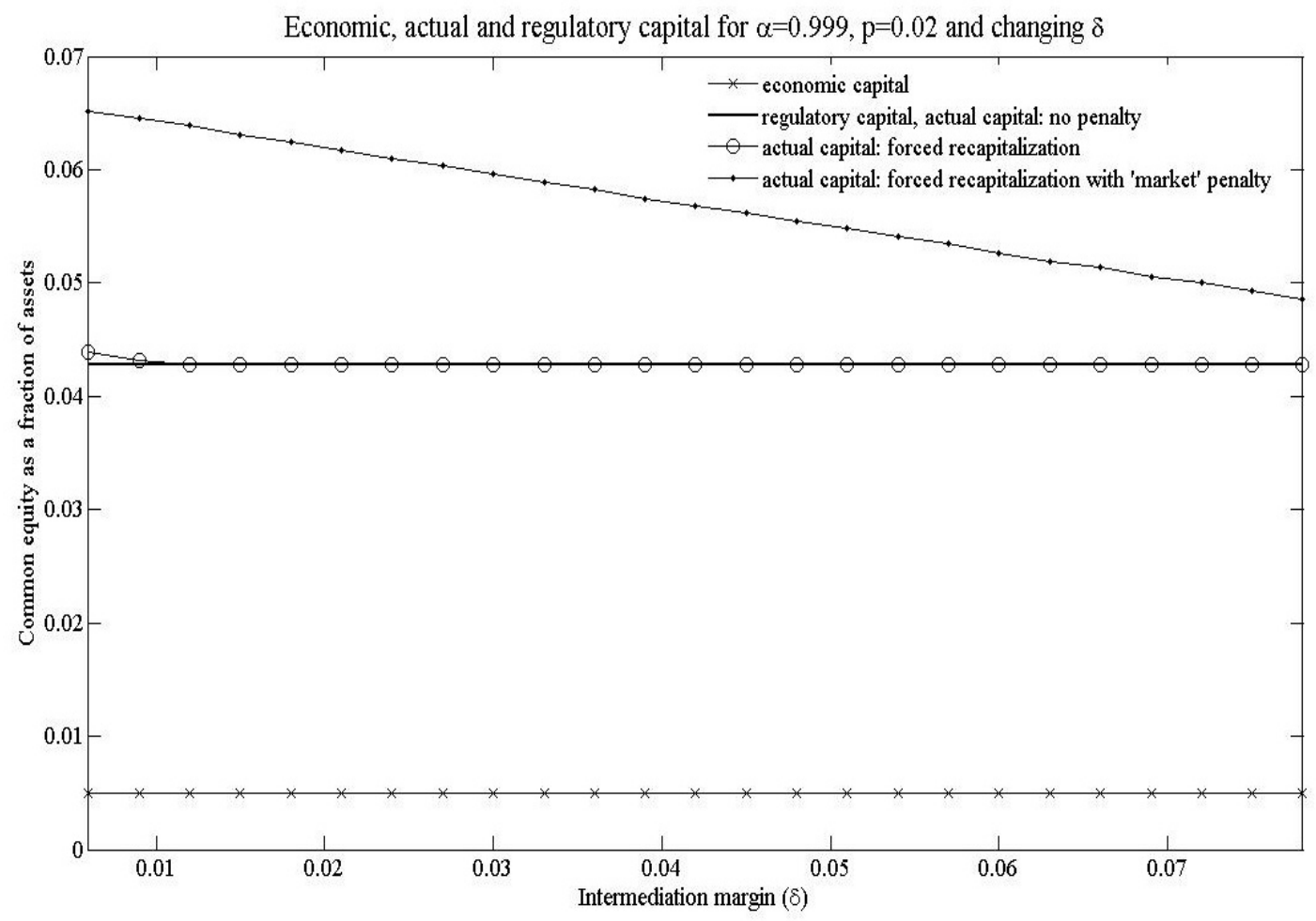

Figure 7: Changes in actual, economic and regulatory capital with respect to the intermediation margin $\delta, \alpha=0.999$ and $\bar{p}=0.02$. 

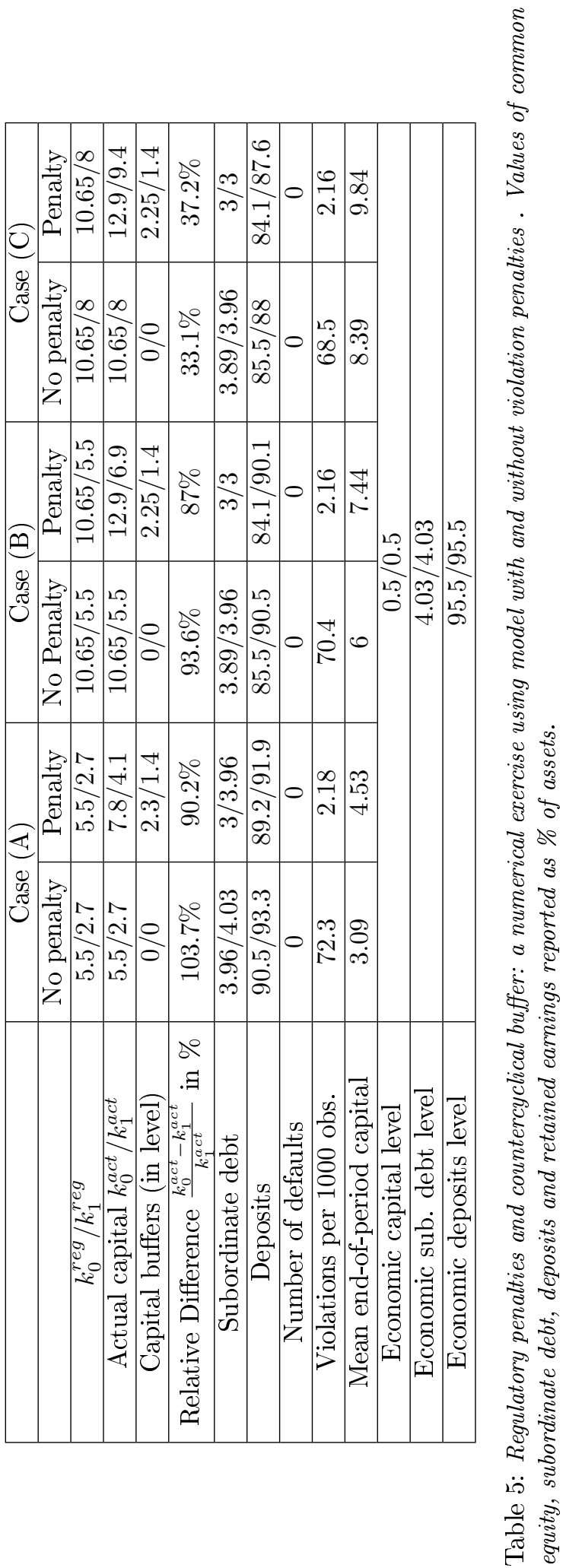